Article

\title{
Revisiting the Foraging Ecology and Extinction History of Two Endemic Vertebrates from Tenerife, Canary Islands
}

\author{
Brooke Erin Crowley ${ }^{1, *(\mathbb{D} \text {, Yurena Yanes }}{ }^{2}$, Stella Grace Mosher ${ }^{3}{ }^{\mathbb{D}}$ and Juan Carlos Rando ${ }^{4}$ \\ 1 University of Cincinnati, Departments of Geology and Anthropology, Cincinnati, OH 45221, USA \\ 2 University of Cincinnati, Department of Geology, Cincinnati, Ohio 45221, USA; yanesya@ucmail.uc.edu \\ 3 Salt Lake Community College, Division of Natural Sciences, Salt Lake City, UT 84123, USA; \\ stella.g.mosher@gmail.com \\ 4 Universidad de La Laguna, Departamento de Biología Animal, Edafología y Geología, \\ 38200 Santa Cruz de Tenerife, Spain; canariomys@yahoo.es \\ * Correspondence: brooke.crowley@uc.edu; Tel.: +1-513-221-1039
}

Received: 11 January 2019; Accepted: 18 February 2019; Published: 21 February 2019

\begin{abstract}
We used carbon $\left(\delta^{13} \mathrm{C}\right)$ and nitrogen $\left(\delta^{15} \mathrm{~N}\right)$ isotopes to examine the foraging ecology of Tenerife giant rats (Canariomys bravoi) and lizards (Gallotia goliath) in northwestern Tenerife, which until recently, were the island's largest terrestrial vertebrates. We combined new isotope data for $28 \mathrm{C}$. bravoi and 14 G. goliath with published regional data for both species and then compared these with data for co-occurring extant taxa and modern $C_{3}$ plants. Isotope data suggest both extinct species relied primarily on $\mathrm{C}_{3}$ resources and were trophic omnivores. However, the two species appear to have partitioned their resources when living in sympatry. Isotopic overlap between C. bravoi and Rattus spp., and between G. goliath, extant Gallotia galloti, and introduced rabbits (Oryctolagus cuniculus) suggests reliance on similar foods. We radiocarbon dated four C. bravoi and two G. goliath with the most extreme isotope values. These new dates do not settle the question of what triggered the demise of either species. Nevertheless, the data are most consistent with anthropogenically-induced extinction. Temporal isotopic trends contradict expectations if regional climate were responsible, and confidence intervals for radiocarbon dates suggest it is highly likely that both species were present when humans first settled the island.
\end{abstract}

Keywords: Canary Islands; Canariomys bravoi; Gallotia goliath; carbon isotopes; nitrogen isotopes; bone collagen; radiocarbon date; Cueva del Viento; Icod; Buenavista del Norte

\section{Introduction}

Our planet has been undergoing a major extinction event since the late Pleistocene [1]. This is of global concern as biological diversity is critical for maintaining stable ecosystems [2,3]. Determining the ecological roles that now-extinct species played within the ecosystems they inhabited provides critical context for management and conservation of remaining biota, e.g., [4-10].

Island vertebrates have been particularly vulnerable to recent, anthropogenically-driven species loss due to their low genetic diversity and evolution in relative isolation from diseases, parasites, competitors, and predators [11-16]. Like most archipelagos, The Canary Islands, which are part of the Mediterranean biodiversity hotspot [17], have experienced multiple Late Holocene vertebrate extinctions [18-23], and a large number of extant native species are currently threatened [24].

Here we use carbon $\left(\delta^{13} \mathrm{C}\right)$, and nitrogen $\left(\delta^{15} \mathrm{~N}\right)$ isotope values in bone collagen combined with radiocarbon $\left({ }^{14} \mathrm{C}\right)$ dates to investigate the diet and extinction chronology for two extinct taxa, the Tenerife giant rat (Canariomys bravoi) and the Tenerife giant lizard (Gallotia goliath). Canariomys bravoi 
was one of two species of giant extinct murines that were endemic to the Canaries [25]. Its congener, Canariomys tamarani, lived on Gran Canaria. The genus has tentatively been placed within the Arvicanthi tribe of the African Murinae [26], or as a sister group to this tribe [27], but this needs to be verified genetically $[28,29]$. Canariomys bravoi weighed slightly less than one kilogram [27]. Postcranial morphofunctional analyses suggest it was a very muscular species that was equally adept in the trees and on the ground. It may also have had some modest digging capabilities [27]. On the basis of mandibular morphology and molar microwear, it likely relied heavily on foliage and may have been an opportunistic omnivore [26,30].

Gallotia goliath was a species of large lacertid lizard that was likely restricted to Tenerife [31]. Two extant species of Gallotia persist on the island: G. intermedia, and G. galloti (reviewed in [31]). Gallotia goliath was larger than the extant species and is thought to have been close to one meter in length, ca. $0.9 \mathrm{~m}$, [32]. In continental settings, lacertid lizards are primarily insectivorous (reviewed in [33]). However, on islands, lacertids tend to be more herbivorous, and extant Gallotia species on Tenerife and other islands in the Canary Archipelago rely heavily on plant matter, e.g., [34-36]. For example, fecal analysis suggests that the extant Tenerife lizard, G. galloti is omnivorous, consuming both arthropods and a considerable amount of fruit in northwestern Tenerife [37-39]. The degree of herbivory in living Gallotia appears to be positively related to body size (i.e., larger-bodied species have longer and more robust guts, more teeth, and stronger jaws that enable them to process fruit [40]). As G. goliath was, on average, larger than living species of Gallotia, it may be reasonable to presume that the larger G. goliath was primarily herbivorous.

The extinction history of $C$. bravoi is relatively well established. On the basis of available ${ }^{14} \mathrm{C}$ dates, authors have previously concluded that the species' demise was likely coincident with initial human arrival on Tenerife, and although hunting by the aboriginal people cannot be completely ruled out, factors like predation, competition for resources with introduced species, and exposure to new parasites and diseases could have been involved in the extinction process, acting either separately or synergistically $[18,23]$. However, next to nothing is known about the extinction history of G. goliath. Just one date has been published (5650 \pm 65 calendar years before present or Cal BP [23]). Competition with introduced taxa or habitat loss are plausible explanations, although predation by introduced cats (Felis domesticus) is also possible. Cats have decimated songbird and extant lizard populations in recent decades [41,42].

The foraging ecology of both taxa has been previously evaluated using stable carbon $\left({ }^{13} C\right)$ and nitrogen $\left(\delta^{15} \mathrm{~N}\right)$ isotopes, e.g., [43-46]. However, results from these studies differ. For example, on the basis of elevated $\delta^{13} \mathrm{C}$ and $\delta^{15} \mathrm{~N}$ values, Arnay-de-la-Rosa and colleagues [45] suggested that C. bravoi and G. goliath were both omnivores that consumed some animal protein. It is not clear from where their specimens originated or what their sample sizes were. Conversely, using data for seven C. bravoi and six G. goliath from multiple localities on Tenerife, Bocherens and colleagues [44] asserted that both species were herbivores that consumed $C_{3}$ plants in a slightly wetter environment than today, and proposed that $C$. bravoi primarily consumed leaves, fruits, and seeds from relatively open habitats or tree canopies. These alternative interpretations likely reflect small sample sizes, spatial isotopic variability among locations on Tenerife, and lack of comparative data from other co-occurring taxa or environmental baselines. Bocherens et al. [18] further noted a decline in $\delta^{15} \mathrm{~N}$ values over time for five radiocarbon-dated giant rats, and concluded that this most likely reflected a shift in temperature over time. This intriguing result needs to be verified with a larger dataset.

We present new carbon and nitrogen isotope data for $28 \mathrm{C}$. bravoi and $14 \mathrm{G}$. goliath, as well as comparative data for a variety of co-occurring extant species. We focused on northwestern Tenerife, which has yielded abundant remains of now-extinct lizards and rats. We also present new radiocarbon $\left({ }^{14} \mathrm{C}\right)$ dates for four giant rats and two giant lizards. We combine our new dataset with previously published and unpublished isotope data for C. bravoi and G. goliath as well as modern plants from the region to reevaluate each species' foraging ecology and most likely extinction window. 
Our results support broad dietary niches for both species; temporal data are most consistent with anthropogenically-induced extinctions.

\subsection{Stable Isotopes in Bone Collagen}

The isotopic composition of vertebrate bone collagen incorporates long-term environmental and ecological information. Carbon isotope values are most frequently used to identify diet. Most woody plants and herbs use $C_{3}$ photosynthesis. Conversely, many kinds of grass use $C_{4}$ photosynthesis. Some (but not all) succulents rely on a third type of photosynthesis called crassulacean acid metabolism (CAM). Thanks to fundamental differences in how each group fixes carbon, there are pronounced differences in their $\delta^{13} \mathrm{C}$ values. $\mathrm{C}_{3}$ plants have values ranging from -20 to $-37 \%$ (global average of $-28.5 \%$ ), $\mathrm{C}_{4}$ plants typically have $\delta^{13} \mathrm{C}$ values between -12 and $-14 \%$, and CAM plants can exhibit $\delta^{13} \mathrm{C}$ values comparable to those of $\mathrm{C}_{4}$ or $\mathrm{C}_{3}$ plants depending on water stress and degree of succulence $[47,48]$. These differences are passed on to animal consumers with some fractionation. Herbivore collagen is typically enriched in ${ }^{13} \mathrm{C}$ by $\sim 5 \%$ relative to diet (reviewed in [49]), and faunivores (animals that consume vertebrate flesh or arthropods) have only slightly higher $\delta^{13} \mathrm{C}$ values than their herbivore prey (on the order of $1 \%$, e.g., [50]. Nitrogen isotope values are typically used to interpret trophic level. Within any given locality, herbivores have higher $\delta^{15} \mathrm{~N}$ values than plants, and faunivores have higher $\delta^{15} \mathrm{~N}$ values than herbivores. The degree of ${ }^{15} \mathrm{~N}$ enrichment varies slightly under different conditions and among taxa, but is typically considered to be on the order of 3 to $5 \%$ per trophic level (reviewed in [49]). Consequently, dietary differences among co-occurring individuals or species can be inferred using these two isotopes.

Importantly, $\delta^{13} \mathrm{C}$ and $\delta^{15} \mathrm{~N}$ values in plants (and the animals that consume them) are also influenced by temperature, precipitation, and relative humidity [51-53]. Dry, hot environments have higher $\delta^{13} \mathrm{C}$ and $\delta^{15} \mathrm{~N}$ values than cool, moist ones. Additionally, within forested habitat, plants growing close to the forest floor (and the animals that consume them) can have substantially lower $\delta^{13} \mathrm{C}$ values than is typical of canopy vegetation, e.g., [54-57]. This "canopy effect" is caused by higher relative humidity, lower light availability, and incorporation of microbe-respired $\mathrm{CO}_{2}$ by understory plants. Lastly, individuals living near the ocean, or consuming marine foods, can have elevated $\delta^{13} \mathrm{C}$ and $\delta^{15} \mathrm{~N}$ values, e.g., [58-61]. It is critical to account for the influence of habitat when interpreting isotope data, particularly when comparing individuals from different localities.

\subsection{Regional Setting}

The Canary Islands are a volcanic archipelago of seven main islands located ca. $100 \mathrm{~km}$ off the Moroccan coast (Figure 1). Tenerife is the largest, tallest, and most biodiverse of the Canaries (reviewed in [24]). The climate is Mediterranean with a brief rainy season that typically falls between November and December [62,63]. Tenerife's northern slope, where this study takes place, is divided into several bioclimatic zones that are distinguished based on their rainfall, temperature, and plant communities $[24,64,65]$. From the coast inland, temperatures decrease and precipitation increases, which strongly affects the vegetation (reviewed in [65]). Succulent scrub is prevalent from the coastline up to approximately $300 \mathrm{~m}$ above sea level (asl), thermophilous forest is found between ca. 300 and $500 \mathrm{~m}$ asl, cloud forest sits between ca. 500 and $1200 \mathrm{~m}$ asl, and pine forest characterizes the highest elevations between ca. 1200 and $2000 \mathrm{~m}$ asl [24].

Past climate conditions in northwestern Africa and the Canary Islands have been inferred using a variety of proxies. Oxygen isotope records from mollusk shells indicate that temperatures have not fluctuated dramatically over the past 20,000 years [66]. However, precipitation has varied considerably. The Late Pleistocene was characterized by relatively dry conditions [66-68]. Climate is thought to have abruptly become moister ca. 14,800 years ago thanks to a strengthening of the North African Monsoon (reviewed in [68]). Conditions became drier again between ca. 13,400 and 12,300 years ago (roughly corresponding with the Younger Dryas event recorded in Europe and North America) but then returned to a moister state until roughly 7600 years ago $[68,69]$. This relatively moist period, 
which is referred to as the African Humid Period, was punctuated by brief spikes in aridity every 1000 to 2000 years (ca. 9600, 8500, 7500, 6500, and 5400 years before the present) that were likely driven by orbital cycling [67-69]. Climate gradually transitioned towards more arid conditions until 4700 to 5500 years ago and has been relatively dry to the present day. Periodic spikes in aridity have continued to occur every ca. 1430 years, with particularly arid periods recorded ca. 4700 to 4000,2700 and 1300 years before present [69].

The precise timing of initial human arrival on Tenerife is unknown. Currently, the earliest reliable presence of humans on Tenerife, based on radiocarbon dated bones from humans an introduced species, is ca. 1270 to 1300 Cal BP [23]. However, dates for introduced species on eastern islands (e.g., Mus musculus on Lanzarote [70]) provide evidence that people were in the Canaries by 1700 Cal BP. Pre-Hispanic settlers have been implicated in the extinction of the dune shearwater (Puffinus holeae) [21], whereas other extinct endemic species, such as the lava shearwater (P. olsoni) and the lava mouse (Malpaisomys insularis) persisted until European contact [22,71]. There is also evidence for early anthropogenic modification of vegetation [72,73]. Following European conquest, anthropogenic activities significantly reduced native vegetation on Tenerife, particularly at lower elevations $[24,65]$. Habitat fragmentation, exotic plants, and domesticated animals (and their associated diseases) continue to impact native flora and fauna to the present day [74-77].

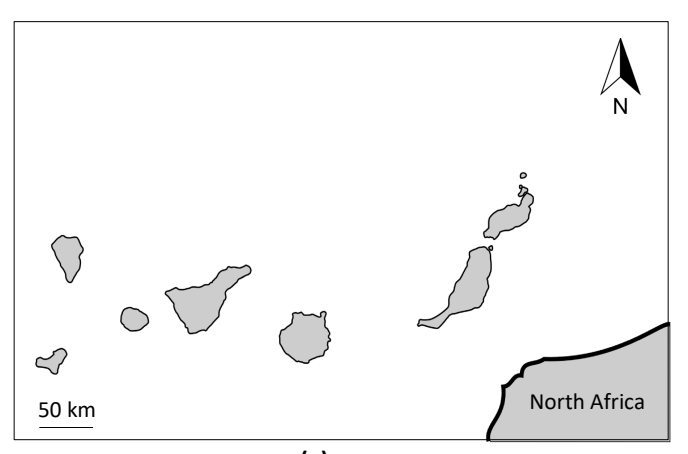

(a)

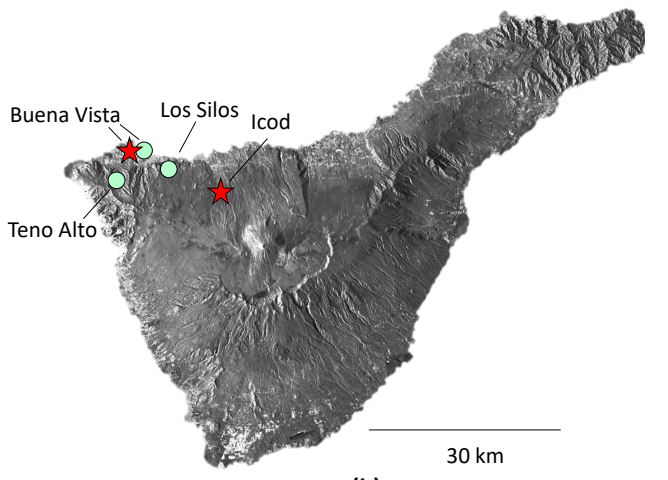

(b)

Figure 1. Maps of (a) the Canary Islands and (b) Tenerife. Fossil localities are indicated with red stars, and plant collection localities are indicated with green circles. The regional map is from Wikimedia Commons [78]; modified Tenerife base map is from Airbus Defence and Space [79].

\section{Materials and Methods}

\subsection{Site Description and Sample Collection}

Our sample included vertebrate specimens that were collected from two sites in northwestern Tenerife: Cueva del Viento, which is a large lava tube located ca. $600 \mathrm{~m}$ asl in the Icod municipality, and the "Golf Cave", which is a small, previously undescribed lava tube that is adjacent to a golf course in the coastal Buenavista del Norte Municipality (Figure 1).

The materials from Cueva del Viento were recovered from the floor of a remote gallery called "Galería de Los Pájaros". The entrance to this part of the cave is ca. $700 \mathrm{~m}$ asl and currently blocked by rocks and sediments. Bones from the Golf Cave were surface collected from the floor of the small lava tube. In both locations, many remains were articulated, suggesting the absence of movement or disturbance after death. Specimens from Cueva del Viento were consolidated by immersing them in Paraloid B72 synthetic resin diluted in acetone (10\%). Bones were identified through comparison with material stored in the vertebrate collection at the Departamento de Zoología in La Laguna University (DZUL), Canary Islands.

In total, we analyzed 28 C. bravoi from Cueva del Viento and 14 G. goliath from the Golf Cave. We also analyzed bones from several extant taxa that were available from each site. At Cueva del Viento, this included two European sparrowhawks (Accipiter nisus) and one common buzzard (Buteo buteo). 
At the Golf Cave, we were able to include four extant Tenerife lizards (G. galloti), as well as several introduced taxa: two murid rats (Rattus rattus or R. norvegicus), one ferret (Mustela furo), and two rabbits (Oryctolagus cuniculus). Analyzing these extant species provided useful comparative isotope data for interpreting data for now-extinct taxa. Buzzards are broad-spectrum predators that feed on a range of vertebrate prey from a variety of habitats, including introduced rabbits and rodents [80,81]. Sparrowhawks, on the other hand, are more forest-dependent, and primarily consume woodland songbirds [82,83]. Ferrets, which were introduced to the Canary Islands by Europeans [84], are also faunivores. Their diet has not been studied in the Canary Islands, but they were historically used for hunting rabbits [84]. On other islands where they have been introduced (e.g., New Zealand and Ireland), they primarily consume rabbits, but also eat other small-bodied mammals, birds, and invertebrates [85-87]. The various species of Rattus are opportunistic and generalist consumers. They eat arthropods, eggs, small vertebrates, and a variety of plant foods [88-90]. The extant Tenerife lizard consumes arthropods and fruit [37-39]. Lastly, rabbits are dedicated herbivores that consume foliage from a variety of herbaceous and woody species [91,92].

\subsection{Sample Preparation and Analysis}

We coarsely fragmented ca. $200 \mathrm{mg}$ of each bone using an agate mortar and pestle or tin snips. We removed Paraloid B72 from the Cueva del Viento specimens following the protocol outlined by France and colleagues for removing polyvinyl acetate [93]. Samples were soaked in acetone for $24 \mathrm{~h}$, rinsed $5 x$ with ultrapure water, and allowed to air dry. Following solvent treatment, Paraloid has no influence on isotope values in bone collagen [93]. We then chemically processed samples to isolate collagenous residues following Sparks and Crowley [61]. Samples were demineralized in $0.5 \mathrm{~N} \mathrm{HCl}$ at $4{ }^{\circ} \mathrm{C}$ for $4-7$ days until they were soft, and rinsed $5 x$ with ultrapure water. We then removed humic acids by soaking samples in $0.01 \mathrm{~N} \mathrm{NaOH}$ for ca. $2 \mathrm{~h}$ at room temperature. Samples were again rinsed $5 x$ with ultrapure water and lyophilized. Lastly, we gelatinized samples in $0.01 \mathrm{~N} \mathrm{HCl}$ at $80{ }^{\circ} \mathrm{C}$ for 15 to $17 \mathrm{~h}$. Roughly $100 \mu \mathrm{L}$ of $0.1 \mathrm{~N} \mathrm{HCl}$ was added after several hours to maintain acidity [94]. We filtered dissolved samples through $1.5 \mu \mathrm{m}$ glass fiber filters, and lyophilized them.

Approximately $0.3 \mathrm{mg}$ of collagenous residue from each sample was weighed into tin boats. We analyzed the samples at the University of Cincinnati Stable Isotope Biogeochemistry Laboratory on a Costech Elemental Analyzer (ECS4010) connected to a Thermo Delta V continuous flow mass spectrometer via a Conflo IV interface. Carbon and nitrogen isotope ratios are reported relative to Vienna Peedee Belemnite (VPDB) and Ambient Inhalable Reservoir (AIR), respectively. We corrected for linearity and drift using caffeine, and scale using caffeine and USGS 41 [95]. Accuracy (based on independent reference materials glycine and gelatin) was $0.11 \%$ for carbon and $0.12 \%$ for nitrogen. Precision (based on all four reference materials) was $0.10 \%$ and $0.11 \%$ for carbon and nitrogen, respectively. The average difference between replicate analyses for six samples run in duplicate was $0.041 \pm 0.03 \%$ and $0.36 \pm 0.34 \%$ for carbon and nitrogen, respectively.

We selected four C. bravoi and two G. goliath individuals with the most extreme $\delta^{13} \mathrm{C}$ and $\delta^{15} \mathrm{~N}$ values to radiocarbon date. Samples were dated at the Center for Accelerator Mass Spectrometry (CAMS), at Lawrence Livermore National Labs, or the W.M. Keck Carbon Cycle Accelerator Mass Spectrometer Facility at the University of California at Irvine (UCI). Conventional radiocarbon age estimates were based on a 5568-year half-life and ${ }^{13} \mathrm{C}$-corrected. Radiocarbon dates were converted to calendar years before present (Cal BP) using Calib 7.1 [96] and the IntCal13 Calibration curve [97]. We report three calibrated age estimates: $2 \sigma$ date ranges (including all intervals with $>10 \%$ probability), mean $\pm 1 \sigma$ dates, and median dates provided by Calib 7.1. All ages were rounded to the nearest five years.

\subsection{Data Analysis}

Collagen preservation was assessed based on visual inspection, collagen yield, and atomic C:N [94]. First, we visually confirmed that isotope data were normally distributed and used Bartlett 
tests to assess the homogeneity of variances. Due to small sample sizes, we used nonparametric Wilcoxon rank sum tests or Kruskal-Wallis tests coupled with post hoc Steel-Dwass all pairs tests to compare taxa within each locality.

Second, we combined our data with previously published data for seven C. bravoi from the Cueva del Viento lava tube complex in the Icod Municipality (El Sobrado, Icod, and "Galeria de Juan José Hernandez Pacheco" in Cueva del Viento proper [44]), as well as published $\delta^{13} \mathrm{C}$ values and previously unpublished $\delta^{15} \mathrm{~N}$ values for three C. bravoi and two G. goliath from small lava tubes (collectively called "Las Arenas") in the Buenavista del Norte municipality ([23,44] J.C.R. previously unpublished data). We refer to these larger, combined datasets based on their municipality ("Icod" and "Buenavista"). All isotope and radiocarbon data are provided in Table S1.

We visually confirmed that the data within each region (Icod or Buenavista) were normally distributed and used Bartlett tests to assess the homogeneity of variances. We used nonparametric Wilcoxon rank sum tests or Kruskal-Wallis tests coupled with post hoc Steel-Dwass all pairs tests to compare (1) data for giant rats or lizards from different localities within Icod or Buenavista, and (2) taxa within each region. We used nonparametric Wilcoxon tests to compare C. bravoi from Icod and Buenavista and parametric two-tailed $\mathrm{t}$-tests or Welch $\mathrm{t}$-tests to compare all data between regions.

Third, we compared measured $\delta^{13} \mathrm{C}$ and $\delta^{15} \mathrm{~N}$ values for animals recovered from Icod and Buenavista with expected values for herbivores and faunivores living in coastal scrub, thermophilous forest, or cloud forest based on modern vegetation. We calculated expected values using isotope data for foliage from common native $C_{3}$ plants that were collected from relatively pristine localities in northwestern Tenerife [98], and commonly used collagen-diet offsets for herbivores $(+5 \%$ for carbon; $+3 \%$ for nitrogen) and faunivores $\left(+1 \%\right.$ and $+3 \%$ relative to $\delta^{13} \mathrm{C}$ and $\delta^{15} \mathrm{~N}$ values in herbivores, respectively, see Table S2). We also accounted for isotopic changes in atmospheric $\mathrm{CO}_{2}$ following the industrial revolution (the Suess Effect) by adding $+1.5 \%$ o to plant $\delta^{13} \mathrm{C}$ data [99]. We did not attempt to correct for earlier shifts in atmospheric $\mathrm{CO}_{2}$ as they were relatively minor in comparison [100-103].

Fourth, we used linear regressions to examine temporal isotopic trends for C. bravoi and G. goliath at Buenavista and C. bravoi at Icod. We also calculated $95 \%$ and $50 \%$ and confidence intervals (CI) for the available radiocarbon dates for C. bravoi and G. goliath on Tenerife (Table S3) to assess the level of certainty these dates can provide about each species' actual extinction, e.g., [104-107]. All analyses were performed using JMP Pro 13 with significance set at $\alpha=0.05$.

\section{Results}

All sampled specimens appeared robust and well-preserved, and atomic C:N was within the accepted range (2.9-3.6) for all but two C. bravoi (CV12 $=4.0$ and CV24 $=3.7$; Table S1). Isotope values for these two individuals were not unusual, and collagen yield and appearance were similar to other individuals. We, therefore, included both of these specimens in all analyses.

We found considerable isotopic variability among individual C. bravoi at Cueva del Viento and G. goliath at the Golf Cave (Table 1 and Table S1). For C. bravoi, $\delta^{13} \mathrm{C}$ and $\delta^{15} \mathrm{~N}$ values ranged from -21.3 to $-17.6 \%$ o $(-19.7 \pm 0.9 \%$ o $)$ and -1.7 to $5.4 \%$ o $(1.4 \pm 1.5 \% 0)$, respectively. For G. goliath carbon ranged from -21.9 to $-19.6 \%$ o ( $-20.8 \pm 0.7 \%$ ) while nitrogen ranged from 3.3 to $11.8 \%$ o $(8.0 \pm 2.0 \%$ ). The individuals selected for dating had the most extreme $\delta^{13} \mathrm{C}$ and $\delta^{15} \mathrm{~N}$ values. Mean calibrated radiocarbon dates for four C. bravoi at Cueva del Viento range from $9565 \pm 65$ to 16,960 \pm 435 Cal BP (Table 2). Dates for G. goliath at the Golf Cave were younger, and both individuals had similar mean calibrated ages: $6060 \pm 125$ and $5745 \pm 140$ Cal BP (Table 2). 
Table 1. Summary isotopic data for taxa recovered from Icod and Buenavista del Norte. Raw isotope data for all individuals are provided in Table S1.

\begin{tabular}{|c|c|c|c|c|c|c|c|c|c|}
\hline \multirow[t]{2}{*}{ Municipality } & \multirow[t]{2}{*}{ Site } & \multirow[t]{2}{*}{ Genus and Species } & \multirow[t]{2}{*}{ Common Name } & \multicolumn{2}{|r|}{$\delta^{13} \mathrm{C}(\%)$} & \multicolumn{3}{|c|}{$\delta^{15} \mathrm{~N}(\% \circ)$} & \multirow[t]{2}{*}{ Source $^{1}$} \\
\hline & & & & $\mathbf{N}$ & Mean $\pm 1 \sigma$ & Median & Mean $\pm 1 \sigma$ & Median & \\
\hline \multirow{2}{*}{\multicolumn{10}{|c|}{ Cueva del Viento }} \\
\hline & & & & & & & & & \\
\hline & & Accipiter nisus & $\begin{array}{l}\text { Macaronesian } \\
\text { sparrowhawk }\end{array}$ & 2 & $-19.7 \pm 2.4$ & -19.7 & $8.3 \pm 1.5$ & 8.3 & 1 \\
\hline & & Buteo buteo & Common buzzard & 1 & -18.3 & -18.3 & 8.5 & 8.5 & 1 \\
\hline & & Canariomys bravoi & Extinct giant rat & 31 & $-19.7 \pm 0.8$ & -19.6 & $1.6 \pm 1.8$ & 1.8 & 1,2 \\
\hline & Icod & Canariomys bravoi & Extinct giant rat & 1 & -19.5 & -19.5 & 2.8 & 2.8 & 2 \\
\hline & El Sobrado & Canariomys bravoi & Extinct giant rat & 3 & $-19.6 \pm 0.1$ & -19.7 & $1.8 \pm 1.9$ & 1.7 & 2 \\
\hline & Golf Cave & Gallotia galloti & Tenerife lizard & 4 & $-19.6 \pm 1.6$ & -19.6 & $6.7 \pm 1.5$ & 6.4 & 1 \\
\hline & Golf Cave & Oryctolagus cuniculus & Rabbit & 2 & $-18.0 \pm 2.3$ & -18.0 & $5.2 \pm 1.0$ & 5.2 & 1 \\
\hline & Golf Cave & Rattus sp. & Rat & 2 & $-19.2^{2}$ & $-19.2^{2}$ & $9.4 \pm 2.3$ & 9.4 & 1 \\
\hline & Golf Cave & Mustela furo & Ferret & 1 & -18.9 & -18.9 & 7.3 & 7.3 & 1 \\
\hline & Las Arenas 3 & Canariomys bravoi & Extinct giant rat & 3 & $-16.5 \pm 0.7$ & -16.8 & $9.7 \pm 0.3$ & 9.6 & 3,4 \\
\hline & Las Arenas ${ }^{3}$ & Gallotia goliath & Extinct giant lizard & 2 & $-20.3 \pm 2.5$ & -20.3 & $6.4 \pm 5.1$ & 6.4 & $2-4$ \\
\hline
\end{tabular}

${ }^{1}$ Sources for isotope data: $1=$ This paper, $2=$ Bocherens et al. [44], $3=$ Rando et al. [23] $\left(\mathfrak{\delta}^{13} \mathrm{C}\right.$ data), $4=$ previously unpublished $\delta^{15} \mathrm{~N}$ values provided by J.C.R. ${ }^{2}$ Summary data for carbon exclude the Rattus sp. with a very high $\delta^{13} \mathrm{C}$ value $\left(-12.0 \%\right.$ o). ${ }^{3}$ Specimens came from multiple caves at Arenas. All three C. bravoi come from Arenas 3 . One G. goliath was collected at

Arenas 1, and no information beyond "Cueva de la Arena" is available for the other individual (H. Bocherens personal communication). 
Table 2. Radiocarbon dates for giant rats and lizards on Tenerife. All calibrated ages were rounded to the nearest five years.

\begin{tabular}{|c|c|c|c|c|c|c|}
\hline Locality & Lab ID $^{1}$ & ${ }^{14} \mathrm{C}$ years $\mathrm{BP}$ & $\begin{array}{l}2 \sigma \text { Calibrated } \\
\text { Date (Cal BP) }\end{array}$ & $\begin{array}{c}\text { Mean } \pm 1 \sigma \text { Calibrated } \\
\text { Date (Cal BP) }\end{array}$ & $\begin{array}{l}\text { Median Calibrated Date } \\
\text { (Cal BP) }\end{array}$ & Source ${ }^{2}$ \\
\hline \multicolumn{7}{|l|}{ Canariomys bravoi } \\
\hline Cueva del Viento & CAMS 167035 & $13,980 \pm 130$ & $16,525-17,395$ & $16,960 \pm 435$ & 16,965 & 1 \\
\hline Cueva del Viento & UCI 184465 & $13,410 \pm 70$ & $15,885-16,355$ & $16,120 \pm 235$ & 16,135 & 1 \\
\hline Cueva del Viento & OxA-54502 & $12,230 \pm 140$ & $13,755-14,820$ & $14,290 \pm 535$ & 14,200 & 2 \\
\hline Cueva del Viento & CAMS 167036 & $9590 \pm 70$ & $10,720-11,170$ & $10,945 \pm 225$ & 10,940 & 1 \\
\hline Cueva del Viento & UCI 184466 & $8595 \pm 35$ & $9500-9630$ & $9565 \pm 65$ & 9545 & 1 \\
\hline Cueva del Viento & GrA 22661 & $5840 \pm 50$ & $6500-6750$ & $6625 \pm 125$ & 6655 & 3 \\
\hline Cueva del Viento & GrA 22658 & $4515 \pm 45$ & $5040-5315$ & $5180 \pm 140$ & 5160 & 3 \\
\hline Cueva del Viento & GrA 22680 & $2305 \pm 40$ & $2155-2380$ & $2270 \pm 113$ & 2330 & 3 \\
\hline Icod & GrA 22656 & $3010 \pm 45$ & $3065-3345$ & $3205 \pm 140$ & 3200 & 3 \\
\hline El Sobrado & GrA 22657 & $3720 \pm 45$ & $3960-4160$ & $4060 \pm 100$ & 4065 & 3 \\
\hline Arenas 3 & KIA 40849 & $5400 \pm 30$ & $6180-6285$ & $6235 \pm 55$ & 6230 & 4 \\
\hline Arenas 1 & KIA 40846 & $3605 \pm 50$ & $3825-4085$ & $3955 \pm 130$ & 3915 & 4 \\
\hline Arenas 3 & KIA 47428 & $2315 \pm 55$ & $2155-2490$ & $2325 \pm 170$ & 2335 & 4 \\
\hline La Fortaleza & WK-28571 & $2304 \pm 32$ & $2180-2360$ & $2270 \pm 90$ & 2335 & 4 \\
\hline \multirow{3}{*}{ Bco. Moraditas } & KIA-36264 & $2275 \pm 25$ & $2180-2350$ & $2265 \pm 85$ & 2315 & 4 \\
\hline & Upper $95 \%$ CI & & & & -1180 & \\
\hline & Upper $50 \%$ CI & & & & 1570 & \\
\hline \multicolumn{7}{|l|}{ Gallotia goliath } \\
\hline Golf Cave & CAMS 166991 & $5265 \pm 35$ & $5935-6180$ & $6060 \pm 130$ & 6050 & 1 \\
\hline Golf Cave & CAMS 166990 & $4975 \pm 40$ & $5605-5880$ & $5745 \pm 140$ & 5700 & 1 \\
\hline \multirow[t]{3}{*}{ Arenas 3} & KIA 47429 & $4895 \pm 40$ & $5585-5715$ & $5650 \pm 65$ & 5630 & 4 \\
\hline & Upper $95 \%$ CI & & & & 4170 & \\
\hline & Upper $50 \%$ CI & & & & 5455 & \\
\hline
\end{tabular}

${ }^{1}$ Radiocarbon lab codes: CAMS $=$ Center for Accelerator Mass Spectrometry, Lawrence Livermore National Labs, U.S.A.; KIA = Kiel AMS, Germany; UCI = Univers
USA; WK = University of Waikato, New Zealand. ${ }^{2}$ Sources for ${ }^{14} \mathrm{C}$ data: $1=$ This paper, $2=$ Michaux et al. [108], $3=$ Bocherens et al. [44]; $4=$ Rando et al. [23]. 
Comparing now-extinct taxa with living taxa at each site, we found that the birds of prey had significantly higher $\delta^{15} \mathrm{~N}$ values than $\mathrm{C}$. bravoi $\left(\chi^{2}=7.89, \mathrm{df}=2, \mathrm{p}=0.019\right)$ and there were no differences in $\delta^{13} \mathrm{C}$ values among taxa at Cueva del Viento (Table 1). Variances were equal among groups for isotopes (Bartlett $\mathrm{p}>0.05$ ). at the Golf Cave, one introduced Rattus sp. had a very high $\delta^{13} \mathrm{C}$ value that was a statistical outlier for the site (Table 1 and Table S1). We anticipate this individual may have consumed some marine or $\mathrm{C}_{4}$ foods (e.g., potentially scavenged from nearby human settlements [44]) and, therefore, excluded it from statistical analyses. Excluding this outlier, carbon and nitrogen isotope data were statistically indistinguishable among taxa at the Golf Cave (Kruskal-Wallis p > 0.05; Bartlett $\mathrm{p}>0.05$ for both isotopes; Table 1 ).

\subsection{Icod Region}

There were no differences in median $\delta^{13} \mathrm{C}$ or $\delta^{15} \mathrm{~N}$ values among the $28 \mathrm{C}$. bravoi individuals analyzed in this study and the six individuals previously analyzed by Bocherens and colleagues [44] from other sites in the Icod Region (Kruskal-Wallis $\mathrm{p}>0.05$; Table 1, Figure 2). Carbon isotope values were significantly more variable for individuals from this study (Bartlett $p=0.026$; Table 1, Figure 2), while $\delta^{15} \mathrm{~N}$ values were significantly more variable for the three previously analyzed individuals from Cueva del Viento (Bartlett $\mathrm{p}=0.0048$; Table 1, Figure 2). We included all individuals in our analysis because there is nothing concerning about any of the data and they are biologically meaningful. Differences in variance among groups could reflect local variability in food resources, microhabitat, or temporal trends. The overall ranges in $\delta^{13} \mathrm{C}$ and $\delta^{15} \mathrm{~N}$ values exhibited by Canariomys in the Icod region were -21.3 to $-18.6 \%$ o $(-19.8 \pm 0.7 \%$ ) and -1.7 to $7.4 \%$ ( $1.5 \pm 1.7 \%$ ), respectively (Figure 2$)$. Predatory birds had similar $\delta^{13} \mathrm{C}$ values $(\mathrm{p}>0.05)$ and significantly higher $\delta^{15} \mathrm{~N}$ values than Canariomys $\left(\chi^{2}=2.73, \mathrm{df}=2, \mathrm{p}=0.0204 ;\right.$ Table 1, Figure 2).

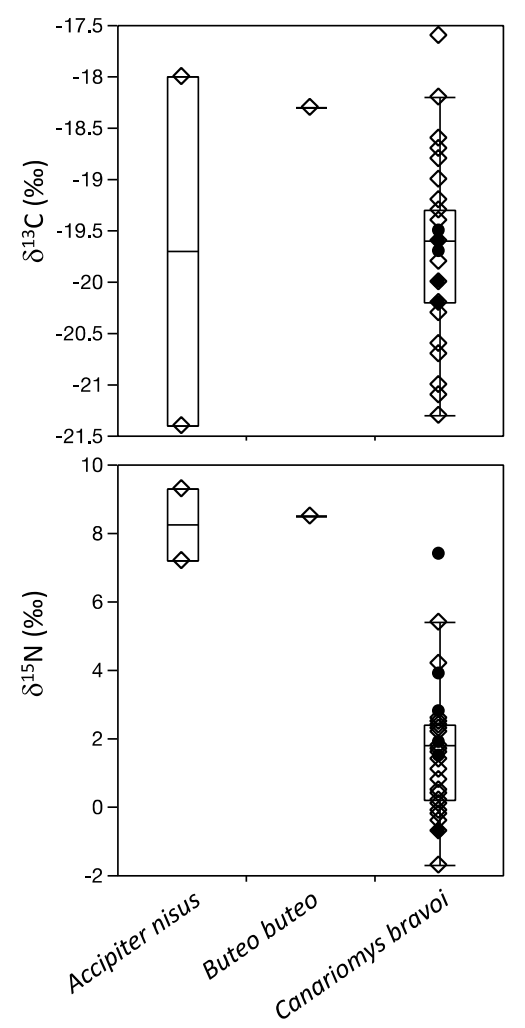

Figure 2. Boxplots comparing $\delta^{13} \mathrm{C}$ and $\delta^{15} \mathrm{~N}$ values for taxa at Icod. Boxes represent 25 and $75 \%$ quartiles, and whiskers contain 1.5 times the interquartile range. Diamond symbols indicate the specimens analyzed in this study. 


\subsection{Buenavista del Norte}

There were no isotopic differences between the 14 G. goliath individuals analyzed from the Golf Cave in this study and the two extinct lizards previously analyzed from Las Arenas (Table 1, [23,44]). We, therefore, include the published data in our regional analysis. Overall, G. goliath exhibited a relatively small range in $\delta^{13} \mathrm{C}$ values $\left(-21.9\right.$ to $-19.6 \% ;-20.8 \pm 0.7 \%$ ) and a $9 \%$ o spread in $\delta^{15} \mathrm{~N}$ values ( 2.8 to $11.8 \%$; $8.0 \pm 2.0 \%$ ). Most individuals had $\delta^{15} \mathrm{~N}$ values between 6 and $10 \%$, while three individuals had exceptionally high $\left(11.8 \%\right.$ ) or low $\delta^{15} \mathrm{~N}$ values $(2.8 ; 3.3 \%$ ). The lowest value (C3-100 [44]) was a statistical outlier for the species. However, we included it in statistical comparisons as it is a published datum and likely biologically meaningful. We also included data for three $C$. bravoi from Las Arenas ([23], J.C.R. previously unpublished data). Variances in $\delta^{13} \mathrm{C}$ values were equal among groups (Bartlett $\mathrm{p}>0.05$ ) and there were significant differences in median $\delta^{13} \mathrm{C}$ values among taxa in the Buenavista del Norte region $\left(\chi^{2}=13.19, \mathrm{df}=5, \mathrm{p}=0.022\right.$; Figure 3$)$. Post hoc tests failed to detect significant differences between pairs of species; nevertheless, it is visually clear that $C$. bravoi had higher $\delta^{13} \mathrm{C}$ values than G. goliath or G. galloti (Figure 3). There were no significant differences in median $\delta^{15} \mathrm{~N}$ values among taxa (Kruskal-Wallis $\mathrm{p}>0.05$; Bartlett $\mathrm{p}>0.05$ ). Excluding the statistical outlier for G. goliath (C3-100 mentioned above) did not change these results. However, there were apparent differences in $\delta^{15} \mathrm{~N}$ values among taxa; Canariomys bravoi had apparently higher $\delta^{15} \mathrm{~N}$ values than G. galloti, Mustela furo, and Oryctolagus cuniculus, and Rattus spp. had higher $\delta^{15} \mathrm{~N}$ values than $O$. cuniculus (Table 1, Figure 3).

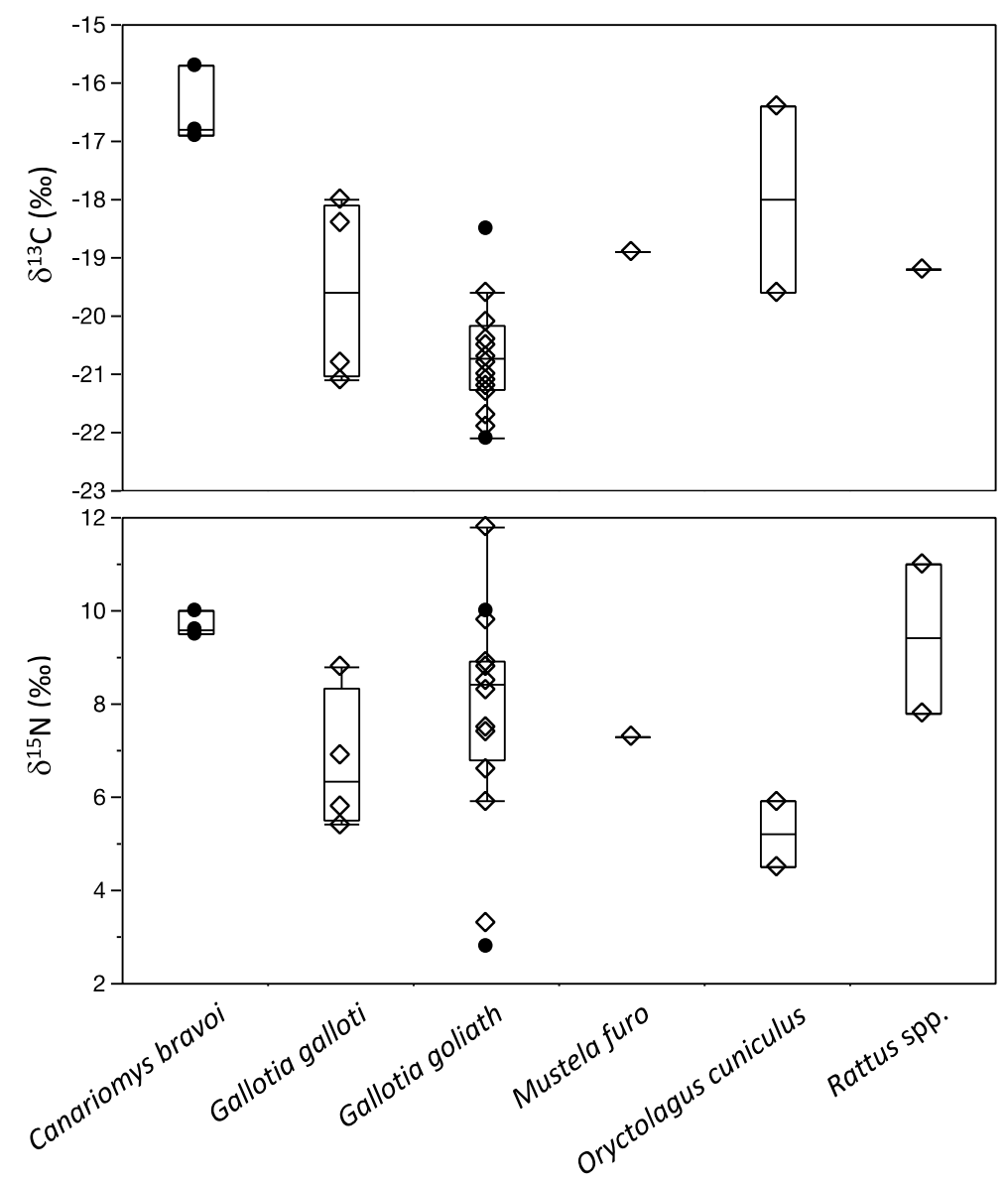

Figure 3. Boxplots comparing $\delta^{13} \mathrm{C}$ and $\delta^{15} \mathrm{~N}$ values for taxa at Buenavista del Norte. Boxes represent 25 and $75 \%$ quartiles, and whiskers contain 1.5 times the interquartile range. Diamonds indicate the specimens analyzed in this study. 


\subsection{Regional Comparison}

Including all individuals from each region, Buenavista del Norte had significantly more variable $\delta^{13} \mathrm{C}$ values (Bartlett $\mathrm{p}=0.0002$ ) than Icod and there were no differences in median $\delta^{13} \mathrm{C}$ values between regions (Welch $\mathrm{T}=0.25, \mathrm{df}=1,35.57, \mathrm{p}=0.81$; Figure 4). Conversely, variances in $\delta^{15} \mathrm{~N}$ values were equal between regions (Bartlett $\mathrm{p}>0.05$ ) and median $\delta^{15} \mathrm{~N}$ values were significantly higher at Buenavista $(\mathrm{T}=-9.44, \mathrm{df}=64, \mathrm{p}<0.0001)$. If we just compared $\mathrm{C}$. bravoi from the two regions, we found no differences in variance for carbon between regions (Bartlett $p>0.05$ ), and individuals from Buenavista had significantly higher $\delta^{13} \mathrm{C}$ values than those from Icod $\left(\chi^{2}=8.11, \mathrm{df}=1, \mathrm{p}=0.0044\right.$; Figure 4). Nitrogen isotopes were significantly more variable and significantly lower for C. bravoi at Icod (Bartlett $\mathrm{p}=0.028 ; \chi^{2}=8.09, \mathrm{df}=1, \mathrm{p}=0.0045 ;$ Figure 4).

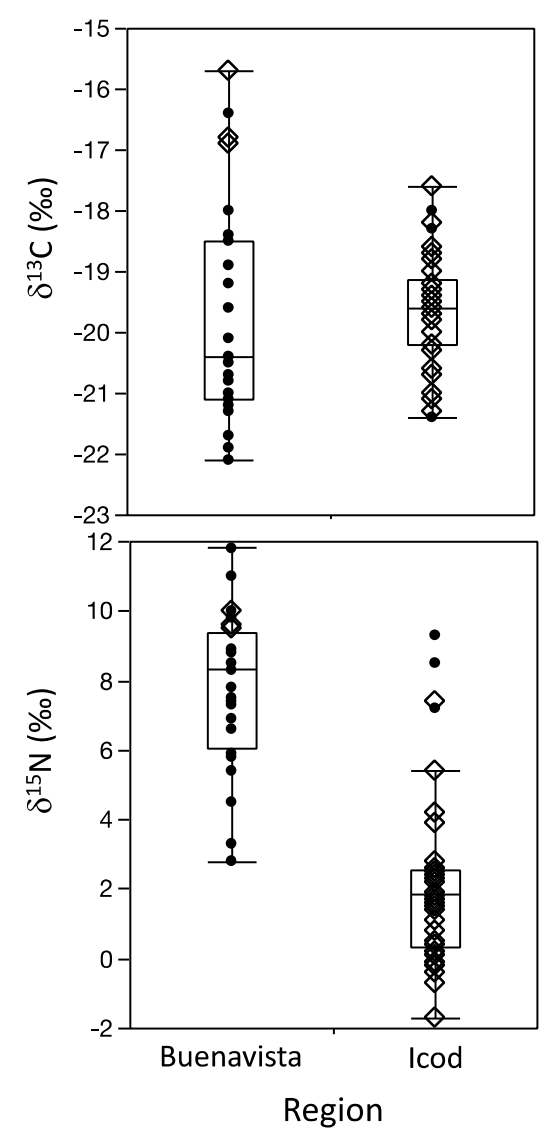

Figure 4. Boxplots comparing $\delta^{13} \mathrm{C}$ and $\delta^{15} \mathrm{~N}$ values for taxa from Icod and Buenavista del Norte. Boxes represent 25 and $75 \%$ quartiles, and whiskers contain 1.5 times the interquartile range. Diamonds demarcate Canariomys bravoi at each site.

In the Icod region, all analyzed individuals had $\delta^{13} \mathrm{C}$ values that are most consistent with thermophilous forest, or possibly coastal scrub (Figure 5). Conversely, most individuals had $\delta^{15} \mathrm{~N}$ values that are more compatible with cloud forest. Overall, fauna at Buenavista del Norte were most coherent with coastal scrub (Figure 5), although one extinct lizard had a $\delta^{15} \mathrm{~N}$ value higher than expected for a coastal scrub faunivore, and one rabbit and one Rattus (the statistical outlier) had higher $\delta^{13} \mathrm{C}$ values than expected for a herbivore consuming purely $C_{3}$ plants (Figure 5 ). Newly analyzed G. goliath and G. galloti were consistent with expectations for coastal scrub herbivores or faunivores or perhaps thermophilous forest faunivores, while the previously analyzed lizard [44] plotted within the space expected for a herbivore from coastal scrub or thermophilous forest. The single Mustela furo and all three C. bravoi were most consistent with coastal scrub faunivores. 

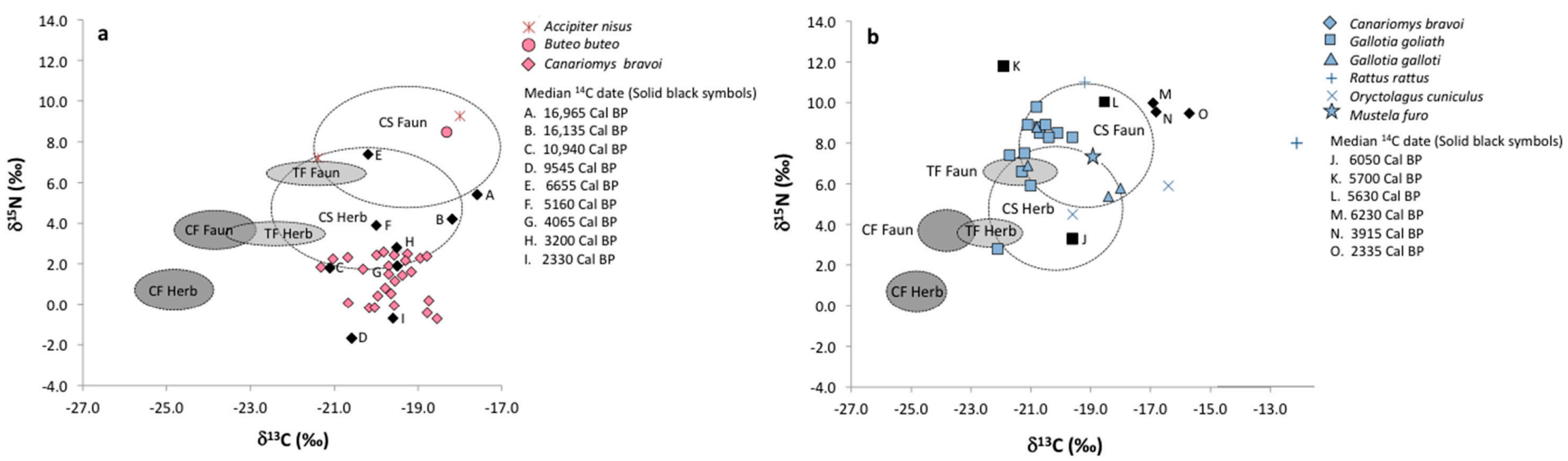

Figure 5. Summary carbon and nitrogen isotope data for taxa from (a) Icod and (b) Buenavista del Norte. Expected $\delta^{13} \mathrm{C}$ and $\delta^{15} \mathrm{~N}$ values (mean $\pm 1 \sigma$ for herbivores (Herb) and faunivores (Faun) living in coastal scrub (CS), thermophilous forest (TF), and cloud forest (CF) are provided in bubbles (see Data Analysis section and Table S2). Radiocarbon-dated individuals are indicated with solid symbols. See Table 2 for date sources. 


\subsection{Temporal Trends}

Including our newly dated specimens, 15 dates exist for C. bravoi and three dates exist for G. goliath on Tenerife (Table 2). The four C. bravoi that we radiocarbon dated from Cueva del Viento were considerably older than the five individuals previously dated by Bocherens et al. [18] in the Icod region, but similar in age to the single individual dated by Michaux et al. [108]. Published dates for giant rats at Las Arenas and other localities (La Fortaleza on Tenerife's western slope, and Barranco de las Moraditas in northeastern Tenerife) are considerably younger (Table 2). Ninety-five percent and $50 \%$ confidence intervals (CI) for median calibrated ${ }^{14} \mathrm{C}$ ages are 3495 and 744 calendar years, respectively (Table S3). The upper 95\% CI for C. bravoi encompasses the present (Table 2) while the more conservative $50 \% \mathrm{CI}$ would place the extinction of this species around $1570 \mathrm{Cal} \mathrm{BP}$. The two G. goliath that we dated at the Golf Cave yielded very similar radiocarbon ages to the extinct giant lizard previously dated by Rando et al. [23] at Arenas (Table 2). The 95\% and 50\% CI for G. goliath are 1458 and 174 calendar years, respectively (Table S3). Upper 95\% and 50\% CI would place the extinction of this species around 4170 and $5455 \mathrm{Cal} \mathrm{BP}$, respectively.

Small sample sizes for dated C. bravoi and G. goliath in the Buenavista del Norte region make it challenging to make robust interpretations of temporal trends. Nevertheless, plotting $\delta^{13} \mathrm{C}$ and $\delta^{15} \mathrm{~N}$ values against median calibrated age is informative. There were no significant correlations between $\delta^{13} \mathrm{C}$ or $\delta^{15} \mathrm{~N}$ values and calibrated ${ }^{14} \mathrm{C}$ age for either species, although there was a slight apparent positive trend between $\delta^{13} \mathrm{C}$ and time, and an apparent negative trend between $\delta^{15} \mathrm{~N}$ and time for C. bravoi (Figure 6). The three dated G. goliath, which all had calibrated ${ }^{14} \mathrm{C}$ ages between 5650 and 6510 $\mathrm{Cal} \mathrm{BP}$, had $\delta^{13} \mathrm{C}$ and $\delta^{15} \mathrm{~N}$ values that varied by $3.4 \% 0$ and $8.5 \%$, respectively (Figure 6). Conversely, ${ }^{14} \mathrm{C}$ ages for the three dated C. bravoi ranged nearly 4000 years $(2325 \pm 170$ to $6235 \pm 55 \mathrm{Cal} \mathrm{BP})$ while $\delta^{13} \mathrm{C}$ and $\delta^{15} \mathrm{~N}$ values varied by just $2.1 \%$ and $0.5 \%$, respectively (Figure 6).

For C. bravoi at Icod, we found an apparent, but insignificant trend in $\delta^{13} \mathrm{C}$ values over time, and no discernable temporal trend for $\delta^{15} \mathrm{~N}$ data (Figure 6). The two oldest individuals (with calibrated ages around 16,000 to $17,000 \mathrm{Cal} \mathrm{BP}$ ) had higher $\delta^{13} \mathrm{C}$ values than other individuals. Excluding these two data points, we found a strong positive relationship between $\delta^{13} \mathrm{C}$ and ${ }^{14} \mathrm{C}$ date $\left(\mathrm{R}^{2}=0.94\right.$, $p=0.0003)$, but continued to observe no relationship between $\delta^{15} \mathrm{~N}$ and ${ }^{14} \mathrm{C}$ date $\left(R^{2}=0.005 ; p=0.88\right)$. Including only those individuals that dated to the mid and late Holocene (i.e., those that are previously published [18,44]), there is a strong, significant negative correlation between $\delta^{15} \mathrm{~N}$ values and ${ }^{14} \mathrm{C}$ date $\left(R^{2}=0.89 ; \mathrm{p}=0.016\right)$. 

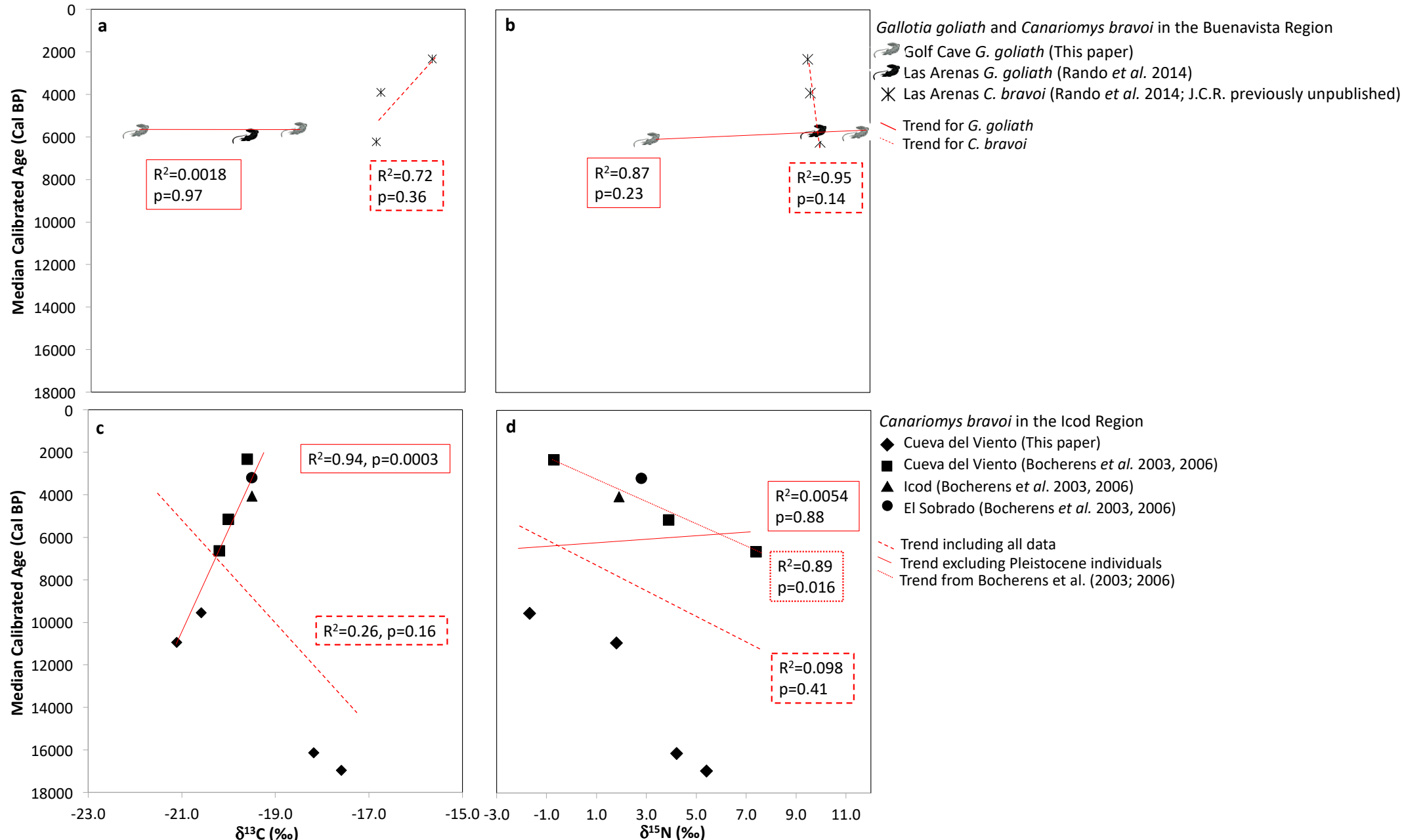

Figure 6. Temporal isotopic trends for (a and b) Canariomys bravoi and Gallotia goliath from the Buenavista del Norte region, and (c and d) C. bravoi in the Icod region. For Icod (panels $\mathrm{c}$ and d), we include trendlines that both include and exclude the two individuals that date to the Pleistocene. We also show the relationship between $\delta^{15} \mathrm{~N}$ and calibrated age using just the data published by Bocherens et al. [18,44]. 


\section{Discussion}

We set out to re-evaluate the foraging ecology and extinction history for Canariomys bravoi and Gallotia goliath, which until quite recently, were Tenerife's largest vertebrates. A diversity of dietary niches has previously been proposed for both extinct species ranging from herbivory to omnivory $[26,30,40,44-46]$.

\subsection{Reconstructing Diet and Habitat for Now-Extinct Taxa}

Carbon and nitrogen isotope data are consistent with C. bravoi and G. goliath both relying primarily (but not exclusively) on $C_{3}$ resources and varying amounts of animal matter in northwestern Tenerife. Giant rats showed a considerable spread in $\delta^{15} \mathrm{~N}$ values at Icod, but with one exception (C8-700; [44]), had lower $\delta^{15} \mathrm{~N}$ values than birds of prey (Figures 2 and 6). Isotope data further suggest that the two extinct species partitioned their resources at Buenavista del Norte. Elevated $\delta^{13} \mathrm{C}$ and $\delta^{15} \mathrm{~N}$ values suggest that $C$. bravoi fed on more CAM or $\mathrm{C}_{4}$ plants and animal matter than G. goliath (Figure 5). Nitrogen data for the two species overlapped; however, all three $C$. bravoi had high $\delta^{15} \mathrm{~N}$ values while G. goliath exhibited a 9\%o range in values (Figures 3 and 6). The larger range in $\delta^{15} \mathrm{~N}$ values exhibited by $G$. goliath suggests individual dietary preferences; some individuals consumed diets that were largely vegetarian while others consumed substantial amounts of animal matter [109].

Both extinct species had higher $\delta^{15} \mathrm{~N}$ values than the herbivorous introduced rabbit (Oryctolagus cuniculus) but similar $\delta^{15} \mathrm{~N}$ values to an introduced Rattus sp. (Figures 3 and 6). There were also qualitative isotopic differences between G. goliath and its extant congener, G. galloti, which has been observed to consume a mix of plant and animal matter [37,39]. Two G. galloti isotopically resembled G. goliath at the Golf Cave; the other two individuals were more similar to rabbits (Figures 3 and 6). Somewhat unexpectedly, the introduced ferret (Mustela furo) from the Buenavista region did not have a particularly elevated $\delta^{15} \mathrm{~N}$ value (although it did plot within the space expected for a coastal scrub faunivore; Figure 5). We suspect that this individual preyed on rabbits [85-87]. It is also possible that this individual escaped from captivity or that it migrated from a site further inland. Home ranges for feral M. furo on New Zealand are 135 to 163 hectares [110]. Thus, it would not be particularly challenging for an individual to traverse the ca. 2 to $3 \mathrm{~km}$ between thermophilous forest and the Buenavista del Norte coastline.

The isotopic overlap between G. galloti, G. goliath and introduced rabbits at Buenavista del Norte suggests these species may consume (or have consumed) similar resources (Figure 5). A substantial isotopic overlap between modern extant lizards and rabbits has also been reported at Punta del Hidalgo/ Dos Hermanos, which is a coastal site in northeastern Tenerife [44]. Likewise, similar $\delta^{15} \mathrm{~N}$ values for $C$. bravoi and one Rattus spp. provide some evidence for dietary overlap. However, rabbits and rats are thought to have been introduced to the Canaries only in the past few hundred years by Europeans $[19,22,23,76]$. It is certainly possible that these introduced taxa compete with G. galloti for resources today, but unlikely that they overlapped temporally with G. goliath or C. bravoi. Overall, isotopic data suggest that portions of the dietary niche occupied by G. goliath and C. bravoi in the coastal northwest may be unfilled today, at least as far as the terrestrial vertebrate community is concerned. Individual G. goliath and C. bravoi had remarkably high $\delta^{15} \mathrm{~N}$ values at Buenavista del Norte (Figure 5). With the exception of the single Rattus sp., none of the other taxa had comparably elevated $\delta^{15} \mathrm{~N}$ values.

The ranges in $\delta^{15} \mathrm{~N}$ values for C. bravoi at Icod $(9.1 \%$ ) and G. goliath at Buenavista del Norte $(9.0 \%$ ) are on par with what we would expect for consumers feeding at three different trophic levels (i.e., ranging from dedicated herbivore to hypercarnivore). However, morphometric and microwear evidence suggest that both species relied heavily on plant foods and were only opportunistic faunivores $[26,30,40]$. Canariomys bravoi had lower $\delta^{15} \mathrm{~N}$ values than co-occurring faunivorous birds of prey at Icod (Figures 2 and 5), which suggests that none of the sampled individuals was a dedicated faunivore.

Additionally, a number of individuals did not plot within the expected range of $\delta^{13} \mathrm{C}$ and $\delta^{15} \mathrm{~N}$ values for herbivores or faunivores living in the habitats that characterize the Icod and Buenavista 
regions today (Figure 5). The Cueva del Viento complex (ca. $600 \mathrm{~m}$ asl) is currently located slightly above the expected elevational cutoff between cloud forest and thermophilous forest (ca. $500 \mathrm{~m}$ asl; [64]). Yet none of the C. bravoi had $\delta^{13} \mathrm{C}$ values that are consistent with cloud or thermophilous forest (Figure 5). Likewise, a number of the specimens analyzed from Buenavista had $\delta^{13} \mathrm{C}$ or $\delta^{15} \mathrm{~N}$ values that fell outside of the expected ranges for $C_{3}$ consumers living in coastal scrub. There are several possible reasons for these results, including the available baseline data, temporal shifts in vegetation or climate, spatial isotopic variability.

First, our baseline isotopic data (mean $\pm 1 \sigma$ for foliage from $C_{3}$ plants collected at a handful of localities in northwestern Tenerife; Figure 1) likely do not capture the full extent of isotopic variability within each biome. There are isotopic differences among localities on Tenerife's northern slope related to exposure to the predominant winds and topography $[98,111]$. Unfortunately, anthropogenic activities have substantially reduced native vegetation cover, and there are only a few relatively undisturbed localities where one can sample plants today [24,65]. Additionally, $\mathrm{C}_{3}$ plants from the succulent scrub exhibit quite variable $\delta^{13} \mathrm{C}$ and $\delta^{15} \mathrm{~N}$ values [98,111]; it would not be surprising if different animal species (and individuals) targeted different plant species. Consumption of different plant parts could also be partially responsible, e.g., [57,112-114]. Lastly, animals may have regularly consumed foods other than $C_{3}$ plants. This is particularly true for introduced species; one rabbit and both Rattus individuals from Buenavista had elevated $\delta^{13} \mathrm{C}$ or $\delta^{15} \mathrm{~N}$ values that would be consistent with consumption of CAM or $\mathrm{C}_{4}$ plants, human foods (e.g., sugarcane or garbage), or marine resources. These results are similar to those that Bocherens and colleagues [44] reported for introduced rabbits and rats at other coastal localities on Tenerife.

Second, shifts in vegetation or climate over time may be partially responsible for the mismatch between expected and observed $\delta^{13} \mathrm{C}$ and $\delta^{15} \mathrm{~N}$ data for $\mathrm{C}$. bravoi in the Icod region. The fog bank that forms between 400 and $1200 \mathrm{~m}$ on the northern slope of Tenerife and is responsible for relatively low $\delta^{13} \mathrm{C}$ values in cloud forest vegetation is caused by orographic uplift of the moisture-laden northeastern trade winds [115]. Regional shifts in climate since the late Pleistocene $[67-69,116]$ may have impacted fog formation, which, in turn, would have affected $\delta^{13} \mathrm{C}$ values for cloud forest vegetation, e.g., [117-119]. As mentioned below, elevated $\delta^{13} C$ values for $C$. bravoi that lived during the Late Pleistocene likely reflect more arid conditions [66,103]. Overall moister conditions during the early and mid-Holocene African Humid Period [67-69] could also explain the relatively low $\delta^{15} \mathrm{~N}$ values for many of the Canariomys individuals from the Icod region (Figure 5). However, climate cannot explain elevated $\delta^{13} \mathrm{C}$ values for individuals that lived during the African Humid Period.

Instead, relatively elevated $\delta^{13} \mathrm{C}$ values for $C$. bravoi from the Icod region could readily be explained by a canopy effect. In forests with closed canopies, such as the cloud forest that characterizes Tenerife's northern slope, foliar $\delta^{13} \mathrm{C}$ values can vary considerably between the forest floor and canopy (e.g., [54-57]). Because all of the vegetation samples available for our isotopic baseline calculations were collected within two meters of the forest floor [98], they may not be representative of canopy vegetation in the cloud forest. Morphofunctional data indicate that now-extinct rats likely spent time foraging within the forest canopy [27]. Thus, the roughly $5 \%$ offset between measured $\delta^{13} \mathrm{C}$ values for giant rats and those expected for cloud-forest consumers would be consistent with an arboreal lifestyle and regular foraging within the forest canopy.

Finally, life in the trees may have also increased the exposure of $C$. bravoi to avian predators. Most skeletons were found intact at Cueva del Viento, which suggests that individuals wandered into the cave on their own. However, transport by an avian predator from a lower elevation could explain the unusually elevated $\delta^{15} \mathrm{~N}$ value for one individual from Bocherens et al. [44] (C8-700, 7.4\%; Figure 2). Transport of prey and subsequent deposition of their remains is not unusual, and these authors [44] suggested this mechanism as an explanation for elevated $\delta^{13} \mathrm{C}$ and $\delta^{15} \mathrm{~N}$ values in a modern Rattus recovered from an inland setting on Tenerife. 


\subsection{Extinction History and Temporal Isotopic Trends for Canariomys bravoi and Gallotia goliath}

New ${ }^{14} \mathrm{C}$ dates for $\mathrm{C}$. bravoi extend the record for this species back to nearly 17,000 calendar years before present. Combining our new radiocarbon dates with those previously published by Bocherens et al. [18] provides a temporal window of nearly 14,700 years at Icod. Elevated $\delta^{13} \mathrm{C}$ and $\delta^{15} \mathrm{~N}$ values for the two C. bravoi with calibrated ages around 16,000 Cal BP (Figures 5 and 6) are consistent with the relatively dry conditions that were prevalent up until the terminal Pleistocene $[66,68]$ while lower $\delta^{13} \mathrm{C}$ and $\delta^{15} \mathrm{~N}$ values for individuals that lived during the early and mid-Holocene are the result of moister conditions that accompanied the African Humid Period [68]. Conversely, intermediate $\delta^{13} \mathrm{C}$ values and highly variable $\delta^{15} \mathrm{~N}$ values for individuals that were alive during the mid to late Holocene, likely reflect the termination of the African Humid Period and onset of more arid conditions (Figures 5 and 6).

The slight positive trend in $\delta^{13} \mathrm{C}$ values through the Holocene for C. bravoi at Icod, is also evident in the smaller published dataset of Bocherens et al. [18] but was not previously discussed. The fact that it continues through the early Holocene, and that it is also observed for C. bravoi at Buenavista del Norte suggests that the temporal trend is real. Changes in the isotopic composition of atmospheric $\mathrm{CO}_{2}$ are an unlikely explanation. Multiple researchers have previously found that atmospheric $\delta^{13} \mathrm{C}$ values only changed by ca. $0.25 \%$ since the late Pleistocene, e.g., [100-103]. Values were slightly lower during the late Pleistocene, increased slightly during the early Holocene, and were subsequently relatively stable until the industrial revolution.

The observed increase in C. bravoi $\delta^{13} \mathrm{C}$ values over time would be consistent with a progressive slight decline in moisture, particularly following the termination of the African Humid Period in the mid-Holocene $[68,69]$. However, the strong, negative correlation between $\delta^{15} \mathrm{~N}$ values and ${ }^{14} \mathrm{C}$ date for younger individuals at Icod (Figure 6) contradicts expectations based on regional climate. Bocherens et al. [18] argued that this trend reflects a reduction in temperatures and increasing aridity over time. Yet regional climate data indicate that temperature has remained relatively constant throughout the Holocene $[66,116]$, and increasing aridity would be expected to result in increased $\delta^{15} \mathrm{~N}$ values, e.g., [51,52]. Moreover, a similar trend is not observed for the individuals at Buenavista (Figure 6). Instead, the strong, negative trend relationship between ${ }^{14} \mathrm{C}$ date and $\delta^{15} \mathrm{~N}$ values for mid to late Holocene $C$. bravoi from the Icod region implicates a shift in diet. The individual with the highest $\delta^{15} \mathrm{~N}$ value at Icod has a mean ${ }^{14} \mathrm{C}$ age of $6625 \pm 25 \mathrm{Cal} \mathrm{BP}$ (Figure 6). This date falls squarely within the African Humid Period, but may also coincide with a minor peak in aridity ca. 6500 years ago that has been documented in southern Spain [69]. Yet the $\delta^{13} \mathrm{C}$ value for this individual is not elevated (Figures 5 and 6), which we would expect if aridity were responsible for the elevated nitrogen value. An alternative explanation is that this individual consumed a considerable amount of animal matter. Lower $\delta^{15} \mathrm{~N}$ values for younger individuals most likely reflects a decrease in omnivory, and we speculate that slightly elevated $\delta^{13} \mathrm{C}$ values combined with lowered $\delta^{15} \mathrm{~N}$ values may indicate an increasing reliance on fruit, e.g., [57,112-114], perhaps in response to shifts in local food resources following the termination of the African Humid Period. Competition with an introduced species, such as the house mouse (Mus musculus) or rat (Rattus sp.) is also possible, although the timing of the observed isotopic shifts suggests this is unlikely. There is no evidence for an early or mid-Holocene human presence on Tenerife and available dates for introduced species are all $<2000 \mathrm{Cal}$ BP $[22,23,76,120]$. We acknowledge that our interpretation of isotopic shifts through time is based on a small number of data. A more comprehensive investigation of temporal isotopic trends will require radiocarbon dating additional specimens.

Regrettably, our expanded dataset for C. bravoi and G. goliath on Tenerife does not settle the question of what caused the demise of Tenerife's giant rats and lizards. Temporal isotopic trends contradict expectations based on regional climate, and last occurrence dates for extinct taxa ( $2265 \pm 85 \mathrm{Cal}$ BP for C. bravoi and $5650 \pm 65 \mathrm{Cal}$ BP for G. goliath) predate the earliest reliable presence of humans on Tenerife. Nevertheless, in the absence of any climatic driver, authors have previously implicated pre-Hispanic people in the extinction of C. bravoi $[23,44]$. Echoing the conclusions of these 
previous authors, the radiocarbon record does not preclude the possibility that humans overlapped temporally with the now-extinct species. Confidence intervals for radiocarbon dated C. bravoi (Table 2) suggest that it is highly likely this species was still present on the island when humans first settled Tenerife. They also demonstrate that we still have very little confidence in when either species actually disappeared. Only three G. goliath have been radiocarbon dated. Further investigation into the timing of extinctions on the island is clearly warranted (Table 2).

\section{Conclusions}

Here we have re-evaluated the foraging ecology of the recently extinct Gallotia goliath and Canariomys bravoi in northwestern Tenerife using carbon and nitrogen stable isotopes. We found substantial evidence for trophic omnivory in both species. Relatively elevated $\delta^{13} \mathrm{C}$ values for $C$. bravoi from the inland Icod municipality also suggest that $C$. bravoi may have regularly foraged in the forest canopy. Slight differences in carbon and nitrogen isotope data further suggest that the two extinct species likely partitioned their resources when living in sympatry. They also indicate that the extant Gallotia galloti, as well as introduced rats and rabbits, may consume resources that are similar to those consumed by G. goliath in coastal habitat. These findings are consistent with morphometric and dental microwear data, which suggest that (1) both species consumed a variety of vegetal and animal foods, and (2) C. bravoi spent time in the trees $[26,27,30,40]$. New radiocarbon dates extend our understanding of the paleoecology of $C$. bravoi during the late Pleistocene but do not help narrow the timing of when either species disappeared from Tenerife. With continued lack of evidence for another driver, we echo the conclusions of Rando et al. [23] that the initial wave of human settlers drove the extinctions of the now-extinct species. Further research on the island will almost certainly refine our understanding of the paleoecology and extinction triggers for both species, and especially lizards.

Supplementary Materials: The following are available online at http:/ www.mdpi.com/2571-550X/2/1/10/s1, Table S1: Stable isotope and radiocarbon data for individual specimens included in this study, Table S2: Published data for foliage from modern $\mathrm{C}_{3}$ plants and expected $\delta^{13} \mathrm{C}$ and $\delta^{15} \mathrm{~N}$ values for herbivores and faunivores that consume $\mathrm{C}_{3}$ plants in each biome, Table S3: $95 \%$ and 50\% confidence interval estimates for last occurrences for Canariomys bravoi and Gallotia goliath.

Author Contributions: Conceptualization, B.E.C. and Y.Y.; Methodology, B.E.C.; Formal Analysis, B.E.C. and J.C.R.; Resources, S.G.M., J.C.R., and Y.Y.; Writing - Original Draft Preparation, B.E.C.; Writing - Review and Editing, B.E.C., S.G.M., J.C.R., and Y.Y.; Visualization, B.E.C.; Funding Acquisition, B.E.C.

Funding: This research was funded by the University of Cincinnati faculty startup funding to B.E.C.

Acknowledgments: We thank Danielle Strasinger and Janine Sparks for assistance with sample preparation, and Tom Guilderson and John Southon for ${ }^{14} \mathrm{C}$ AMS analysis. This research received no specific grant from any funding agency in the public, commercial or not-for-profit sectors. Analyses were funded by faculty startup (to B.E.C.) and the UC Stable Isotope Facility was supported by the National Science Foundation (EAR-1229114).

Conflicts of Interest: The authors declare no conflict of interest.

\section{References}

1. Barnosky, A.D.; Matzke, N.; Tomiya, S.; Wogan, G.O.U.; Swartz, B.; Quental, T.B.; Marshall, C.; McGuire, J.L.; Lindsey, E.L.; Maguire, K.C.; et al. Has the Earth's sixth mass extinction already arrived? Nature 2011, 471, 51-57. [CrossRef] [PubMed]

2. Hooper, D.U.; Adair, E.C.; Cardinale, B.J.; Byrnes, J.E.; Hungate, B.A.; Matulich, K.L.; Gonzalez, A.; Duffy, J.E.; Gamfeldt, L.; O'Connor, M.I. A global synthesis reveals biodiversity loss as a major driver of ecosystem change. Nature 2012, 486, 105-108. [CrossRef] [PubMed]

3. Dunne, J.A.; Williams, R.J.; Martinez, N.D. Network structure and biodiversity loss in food webs: Robustness increases with connectance. Ecol. Lett. 2002, 5, 558-567. [CrossRef]

4. Bond, W.J.; Silander, J.A. Springs and wire plants; anacrhonistic defences against Madagascar's extinct elephant birds. Proc. R. Soc. Lond. 2007, 274, 1985-1992. [CrossRef]

5. Cerling, T.E.; Harris, J.M.; Leakey, M.G. Browsing and grazing in elephants: The isotope record of modern and fossil proboscideans. Oecologia 1999, 120, 364-374. [CrossRef] [PubMed] 
6. Crowley, B.E.; Godfrey, L.R. Why all those spines? Anachronistic defenses in the Didiereoideae against now extinct lemurs. S. Afr. J. Sci. 2013, 109, 70-76. [CrossRef]

7. Gill, J.L.; Williams, J.W.; Jackson, S.T.; Donnelly, J.P.; Schellinger, G.C. Climatic and megaherbivory controls on late-glacial vegetation dynamics: A new, high-resolution, multi-proxy record from Silver Lake, Ohio. Quat. Sci. Rev. 2012, 34, 66-80. [CrossRef]

8. Janzen, D.H.; Martin, P.S. Neotropical anachronisms: The fruits the gomphotheres ate. Science 1982, 215, 19-27. [CrossRef] [PubMed]

9. Newsome, S.D.; Etnier, M.A.; Gifford-Gonzalez, D.; Phillips, D.L.; van Tuinen, M.; Hadly, E.A.; Costa, D.P.; Kennett, D.J.; Guilderson, T.P.; Koch, P.L. The shifting baseline of northern fur seal ecology in the northeast Pacific Ocean. Proc. Natl. Acad. Sci. USA 2007, 104, 9709-9714. [CrossRef] [PubMed]

10. Miller, G.H.; Fogel, M.L.; Magee, J.W.; Gagan, M.K.; Clarke, S.J.; Johnson, B.J. Ecosystem collapse in Pleistocene Australia and a human role in megafaunal extinction. Science 2005, 309, 287-290. [CrossRef]

11. Pimm, S.L.; Jones, H.L.; Diamond, J. On the risk of extinction. Am. Nat. 1988, 132, 757-785. [CrossRef]

12. Milberg, P.; Tyrberg, T. Naïve birds and noble savages: A review of man-caused prehistoric extinctions of island birds. Ecography 1993, 16, 229-250. [CrossRef]

13. Blackburn, T.M.; Cassey, P.; Duncan, R.P.; Evans, K.L.; Gaston, K.L. Avian extinction and mammalian introductions on oceanic islands. Science 2004, 305, 1955-1958. [CrossRef] [PubMed]

14. Burney, D.A.; Flannery, T.F. Fifty millennia of catastrophic extinctions after human contact. Trends Ecol. Evol. 2005, 20, 395-401. [CrossRef] [PubMed]

15. Gillespie, R.G.; Claridge, E.M.; Roderick, G.K. Biodiversity dynamics in isolated island communities: Interaction between natural and human-mediated processes. Mol. Ecol. 2008, 17, 45-57. [CrossRef]

16. Crowley, B.E.; Godfrey, L.R.; Bankoff, R.J.; Perry, G.H.; Culleton, B.J.; Kennett, D.J.; Sutherland, M.R.; Samonds, K.E.; Burney, D.A. Island-wide aridity did not trigger recent megafaunal extinctions in Madagascar. Ecography 2017, 40, 901-912. [CrossRef]

17. Myers, N.; Mittermeier, R.A.; Mittermeier, C.G.; da Fonseca, G.A.B.; Kent, J. Biodiversity hotspots for conservation priorities. Nature 2000, 403, 853-858. [CrossRef]

18. Bocherens, H.; Michaux, J.; Garcia Talavera, F.; Van der Plicht, J. Extinction of endemic vertebrates on islands: The case of the giant rat Canariomys bravoi (Mammalia, Rodentia) on Tenerife (Canary Islands, Spain). C. R. Palevol 2006, 5, 885-891. [CrossRef]

19. Rando, J.C.; Alcover, J.A.; Navarro, J.F.; García-Talavera, F.; Hutterer, R.; Michaux, J. Chronology and causes of the extinction of the lava mouse, Malpaisomys insularis (Rodentia: Muridae) from the Canary Islands. Quat. Res. 2008, 70, 141-148. [CrossRef]

20. Rando, J.C.; López, M.; Seguí, B. A new species of extinct flightless passerine (Emberizidae: Emberiza) from the Canary Islands. Condor 1999, 101, 1-13. [CrossRef]

21. Rando, J.C.; Alcover, J.A. On the extinction of the dune shearwater (Puffinus holeae) from the Canary Islands. J. Ornithol. 2010, 151, 365-369. [CrossRef]

22. Rando, J.C.; Alcover, J.A.; Michaux, J.; Huterrer, R.; Navarro, J.F. Late-Holocene asynchronous extinction of endemic mammals on the eastern Canary Islands. Holocene 2012, 22, 801-808. [CrossRef]

23. Rando, J.C.; Alcover, J.A.; Galván, B.; Navarro, J.F. Reappraisal of the extinction of Canariomys bravoi, the giant rat from Tenerife (Canary Islands). Quat. Sci. Rev. 2014, 94, 22-27. [CrossRef]

24. Fernández-Palacios, J.M.; Whittaker, R.J. The Canaries: An important biogeographical meeting place. J. Biogeogr. 2008, 35, 379-387. [CrossRef]

25. Crusafont-Pairo, M.; Petter, F. Un murine géant fossile des Iles Canaries Canariomys bravoi Gen. nov., sp. nov. (Rongeurs, Muridés). Mamm. Biol. 1965, 28, 607-612. [CrossRef]

26. López-Martinez, N.; López-Jurado, L.F. Un nuevo murido gigante del Cuaternario de Gran Canaria Canariomys tamarani nov. sp. (Rodentia Mammalia). Doñana Publ. Ocas. 1987, 2, 1-60.

27. Michaux, J.; Hautier, L.; Hutterer, R.; Lebrun, R.; Guy, F.; García-Talavera, F. Body shape and life style of the extinct rodent Canariomys bravoi (Mammalia, Murinae) from Tenerife, Canary Islands (Spain). C. R. Palevol. 2012, 11, 485-494. [CrossRef]

28. Lecompte, E.; Aplin, K.; Denys, C.; Catzeflis, F.; Chades, M.; Chevret, P. Phylogeny and biogeography of African Murinae based on mitochondrial and nuclear gene sequences, with a new tribal classification of the subfamily. BMC Evol. Biol. 2008, 8, 199. [CrossRef] 
29. Pàges, M.; Chevret, P.; Gros-Balthazard, M.; Hughes, S.; Alcover, J.A.; Hutterer, R.; Rando, J.C.; Michaux, J.; Haenni, C. Paleogenetic analyses reveal unsuspected phylogenetic affinities between mice and the extinct Malpaisomys insularis, an endemic rodent of the Canaries. PLoS ONE 2012, 7, e31123. [CrossRef]

30. Firmat, C.; Rodrigues, H.G.; Renaud, S.; Claude, J.; Hutterer, R.; Garcia-Talavara, F.; Michaux, J. Mandible morphology, dental microwear, and diet of the extinct giant rats Canariomys (Rodentia: Murinae) of the Canary Islands (Spain). Biol. J. Linn. Soc. 2010, 101, 28-40. [CrossRef]

31. Maca-Meyer, N.; Carranza, S.; Rando, J.C.; Arnold, E.N.; Cabrera, V.M. Status and relationships of the extinct giant Canary Island lizard Gallotia goliath (Reptilia: Lacertidae), assessed using ancient mtDNA from its mummified remains. Biol. J. Linn. Soc. 2003, 80, 659-670. [CrossRef]

32. Barahona, F.; Evans, S.E.; Mateo, J.A.; García-Márquez, M.; López-Jurado, L.J. Endemism, gigantism and extinction in island lizards: The genus Gallotia on the Canary Islands. J. Zool. Lond. 2000, 250, 373-388. [CrossRef]

33. Van Damme, R. Evolution of herbivory in lacertid lizards: Effects of insularity and body size. J. Herpetol. 1999, 33, 663-674. [CrossRef]

34. López-Jurado, L.F.; Mateo, J.A. Origin, colonization, adaptive radiation, intrainsular evolution and species substitution processes in the fossil and living lizards of the Canary Islands. In Scienta Herpetologica; Llorente, G.A., Montori, A., Santos, X., Carretero, M.A., Eds.; Asociación Herpetológica Española: Barcelona, Spain, 1995; pp. 81-91.

35. Mateo, J.A.; Lopez-Jurado, L.F. Study of dentition in lizards from Gran Canaria Island (Canary Islands) and its ecological and evolutionary significance. Biol. J. Linn. Soc. 1992, 46, 39-48. [CrossRef]

36. Naranjo, J.J.; Nogales, M.; Quilis, V. Sobre la presencia de Gallotia stehlini en la isla de Fuerte- ventura (Canarias) y datos preliminares de su alimentación. Rev. Española De Herpetol. 1991, 6, 45-48.

37. Valido, A.; Nogales, M. Frugivory and seed dispersal by the lizard Gallotia galloti (Lacertidae) in a xeric habitat of the Canary Islands. Oikos 1994, 70, 403-411. [CrossRef]

38. Rodríguez, A.; Nogales, M.; Rumeu, B.; Rodríguez, B. Temporal and spatial variation in the diet of the endemic lizard Gallotia galloti in an insular Mediterranean scrubland. J. Herpetol. 2008, 42, 213-222. [CrossRef]

39. Valido, A.; Nogales, M.; Medina, F.M. Fleshy fruits in the diet of Canarian lizards Gallotia galloti (Lacertidae) in a xeric habitat of the island of Tenerife. J. Herpetol. 2003, 37, 741-747. [CrossRef]

40. Valido, A.; Nogales, M. Digestive ecology of two omnivorous Canarian lizard species (Gallotia, Lacertidae). Amphib. -Reptil. 2003, 24, 331-344. [CrossRef]

41. Nogales, M.; Medina, F.M. Trophic ecology of feral cats (Felis silvestris f. catus) in the main environments of an oceanic archipelago (Canary Islands): An updated approach. Mamm. Biol. 2009, 74, 169-181. [CrossRef]

42. Nogales, M.; Vidal, E.; Medina, F.M.; Bonnaud, E.; Tershy, B.R.; Campbell, K.J.; Zavaleta, E.S. Feral cats and biodiversity conservation: The urgent prioritization of island management. BioScience 2013, 63, 804-810. [CrossRef]

43. Tieszen, L.L.; Matzner, S.; Buseman, S.K. Dietary reconstruction based on stable isotopes $\left({ }^{13} \mathrm{C},{ }^{15} \mathrm{~N}\right)$ of the Guanche, pre-hispanic Tenerife, Canary Islands. In Proceedings of the I World Congress on Mummy Studies, Tenerife, Spain, 1992; pp. 41-57.

44. Bocherens, H.; Michaux, J.; Billiou, D.; Castanet, J.; Garcia-Talavera, F. Contribution of collagen stable isotope biogeochemistry to the paleobiology of extinct endemic vertebrates from Tenerife (Canary Islands, Spain). Isot. Environ. Health Stud. 2003, 39, 197-210. [CrossRef] [PubMed]

45. Arnay-de-la-Rosa, M.; González-Reimers, E.; Yanes, Y.; Velasco-Vázquez, J.; Romanek, C.S.; Noakes, J.E. Paleodietary analysis of the prehistoric population of the Canary Islands inferred from stable isotopes (carbon, nitrogen and hydrogen) in bone collagen. J. Archaeol. Sci. 2010, 37, 1490-1501. [CrossRef]

46. Arnay-de-la-Rosa, M.; González-Reimers, E.; Yanes, Y.; Romanek, C.S.; Noakes, J.E.; Galindo-Martín, L. Paleonutritional and paleodietary survey on prehistoric humans from Las Cañadas del Teide (Tenerife, Canary Islands) based on chemical and histological analysis of bone. J. Archaeol. Sci. 2011, 38, 884-895. [CrossRef]

47. O'Leary, M.H. Carbon isotopes in photosynthesis. BioScience 1988, 38, 328-336. [CrossRef]

48. Kohn, M.J. Carbon isotope compositions of terrestrial $C_{3}$ plants as indicators of (paleo)ecology and (paleo)climate. Proc. Natl. Acad. Sci. USA 2010, 107, 19691-19695. [CrossRef] [PubMed]

49. Koch, P.L. Isotopic reconstruction of past continental environments. Annu. Rev. Earth Planet. Sci. 1998, 26, 573-613. [CrossRef] 
50. Fox-Dobbs, K.; Bump, J.K.; Peterson, R.O.; Fox, D.L.; Koch, P.L. Carnivore-specific stable isotope variables and variation in the foraging ecology of modern and ancient wolf populations: Case studies from Isle Royale, Minnesota, and La Brea. Can. J. Zool. 2007, 85, 458-471. [CrossRef]

51. Cormie, A.B.; Schwarcz, H.P. Stable isotopes of nitrogen and carbon of North American white-tailed deer and implications for paleodietary and other food web studies. Palaeogeogr. Palaeoclimatol. Palaeoecol. 1994, 107, 227-241. [CrossRef]

52. Crowley, B.E.; Thorén, S.; Rasoazanabary, E.; Vogel, E.R.; Barrett, M.A.; Zohdy, S.; Blanco, M.B.; McGoogan, K.C.; Arrigo-Nelson, S.J.; Irwin, M.T.; et al. Explaining geographical variation in the isotope composition of mouse lemurs (Microcebus). J. Biogeogr. 2011, 38, 2106-2121. [CrossRef]

53. Hartman, G. Are elevated $\delta^{15} \mathrm{~N}$ values in herbivores in hot and arid environments caused by diet or animal physiology? Funct. Ecol. 2011, 25, 122-131. [CrossRef]

54. van der Merwe, N.J.; Medina, E. The canopy effect, carbon isotope ratios and foodwebs in Amazonia. J. Archaeol. Sci. 1991, 18, 249-259. [CrossRef]

55. Broadmeadow, M.S.J.; Griffiths, H.; Maxwell, C.; Borland, A.M. The carbon isotope ratio of plant organic material reflects temporal and spatial variations in $\mathrm{CO}_{2}$ within the tropical forest formations in Trinidad. Oecologia 1992, 89, 435-441. [CrossRef] [PubMed]

56. Cerling, T.E.; Hart, J.A.; Hart, T.B. Isotope ecology in the Ituri forest. Oecologia 2004, 138, 5-12. [CrossRef]

57. Carlson, B.A.; Crowley, B.E. Variation in carbon isotope values among chimpanzee foods at Ngogo, Kibale National Park and Bwindi Impenetrable National Park, Uganda. Am. J. Primatol. 2016, 78, 1031-1040. [CrossRef]

58. Britton, K.; Müldner, G.; Bell, M. Stable isotope evidence for salt-marsh grazing in the Bronze Age Severn Estuary, UK: Implications for palaeodietary analysis at coastal sites. J. Archaeol. Sci. 2008, 35, 2111-2118. [CrossRef]

59. Reid, R.E.; Gifford-Gonzalez, D.; Koch, P.L. Coyote (Canis latrans) use of marine resources in coastal California: A new behavior relative to their recent ancestors. Holocene 2018, 28, 1781-1790. [CrossRef]

60. Fox-Dobbs, K.; Stidham, T.A.; Bowen, G.J.; Emslie, S.D.; Koch, P.L. Dietary controls on extinction versus survial among avian megafauna in the late Pleistocene. Geology 2006, 34, 685-688. [CrossRef]

61. Sparks, J.M.; Crowley, B.E. Where did people forage in prehistoric Trinidad? Testing the utility of a multi-isotope approach for tracking the origins of terrestrial prey. J. Archaeol. Sci. 2018, 19, 968-978. [CrossRef]

62. Fernández-Palacios, J.M. Climatic responses of plant species on Tenerife, the Canary Islands. J. Veg. Sci. 1992, 3, 595-602. [CrossRef]

63. Balasse, M. Potential biases in sampling design and interpretation of intra-tooth isotope analysis. Int. J. Osteoarchaeol. 2003, 13, 3-10. [CrossRef]

64. Fernández-Palacios, J.M.; María, J.; de Nicolás, J.P. Altitudinal pattern of vegetation variation on Tenerife. J. Veg. Sci. 1995, 6, 183-190. [CrossRef]

65. del-Arco, M.; Pérez-de-Paz, P.L.; Acebes, J.R.; González-Mancebo, J.M.; Reyes-Betancort, J.A.; Bermejo, J.A.; de-Armas, S.; González-González, R. Bioclimatology and climatophilous vegetation of Tenerife (Canary Islands). Ann. Bot. Fenn. 2006, 43, 167-192. [CrossRef]

66. Yanes, Y.; Yapp, C.J.; Ibáñez, M.; Alonso, M.R.; De la Nuez, J.; Quesada, M.L.; Castillo, C.; Delgado, A. Pleistocene-Holocene environmental change in the Canary Archipelago as inferred from stable isotopes of land snail shells. Quat. Res. 2011, 65, 658-669. [CrossRef]

67. Gasse, F. Hydrological changes in the African tropics since the Last Glacial Maximum. Quat. Sci. Rev. 2000, 19, 189-211. [CrossRef]

68. deMenocal, P.; Ortiz, J.; Guilderson, T.; Adkins, J.; Sarnthein, M.; Baker, L.; Yarusinsky, M. Abrupt onset and termination of the African Humid Period: Rapid climate responses to gradual insolation forcing. Quat. Sci. Rev. 2000, 19, 347-361. [CrossRef]

69. Ramos-Román, M.J.; Jiménez-Moreno, G.; Camuera, J.; García-Alix, A.; Anderson, R.S.; Jiménez-Espejo, F.J.; Sachse, D.; Toney, J.L.; Carrión, J.S.; Webster, C.; et al. Millennial-scale cyclical environment and climate variability during the Holocene in the western Mediterranean region deduced from a new multi-proxy analysis from the Padul record (Sierra Nevada, Spain). Glob. Planet. Chang. 2018, 168, 35-53. [CrossRef] 
70. Alcover, J.A.; Rando, J.C.; García-Talavera, F.; Hutterer, R.; Michaux, J.; Trias, M.; Navarro, J.F. A reappraisal of the stratigraphy of Cueva del Llano (Fuerteventura) and the chronology of the house mouse (Mus musculus) introduction into the Canary Islands. Palaeogeogr. Palaeoclimatol. Palaeoecol. 2009, 277, 184-190. [CrossRef]

71. Rando, J.C.; Alcover, J.A. Evidence for a second western Palaearctic seabird extinction during the last Millennium: The lava shearwater Puffinus olsoni. Ibis 2008, 150, 188-192. [CrossRef]

72. de Nascimento, L.; Willis, K.J.; Fernández-Palacios, J.M.; Criado, C.; Whittaker, R.J. The long-term ecology of the lost forests of La Laguna, Tenerife (Canary Islands). J. Biogeogr. 2009, 36, 499-514. [CrossRef]

73. Morales, J.; Rodríguez, A.; Alberto, V.; Machado, C.; Criado, C.; Rando, J.C. The impact of human activities on the natural environment of the Canary Islands (Spain) during the pre-Hispanic stage (3rd-2nd Century BC to 15th Century AD): An overview. Environ. Archaeol. 2009, 14, 27-36. [CrossRef]

74. Dickson, J.H.; Rodriguez, J.C.; Machado, A. Invading plants at high altitudes on Tenerife especially in the Teide National Park. Bot. J. Linn. Soc. 1987, 95, 155-179. [CrossRef]

75. Francisco-Ortega, J.; Santos-Guerra, A.; Kim, S.-C.; Crawford, D.J. Plant genetic diversity in the Canary Islands: A conservation perspective. Am. J. Bot. 2000, 87, 900-919. [CrossRef]

76. Nogales, N.; Rodríguez-Luengo, J.L.; Marrero, P. Ecological effects and distribution of invasive non-native mammals on the Canary Islands. Mamm. Rev. 2006, 36, 49-65. [CrossRef]

77. Carrete, M.; Serrano, D.; Illera, J.C.; López, G.; Vögeli, M. Goats, birds, and emergent diseases: Apparent and hidden effects of exotic species in an island environment. Ecol. Appl. 2009, 19, 840-853. [CrossRef] [PubMed]

78. Wikimedia Commons. Available online: https://commons.wikimedia.org/wiki/File:Blank_Map-Canary_ Islands.svg (accessed on 20 December 2018).

79. Airbus Defence and Space. Available online: http://www.intelligence-airbusds.com/en/67-base-maps (accessed on 20 December 2018).

80. Gangoso, L.; Donázar, J.A.; Scholz, S.; Palacios, C.J.; Hiraldo, F. Contradiction in conservation of island ecosystems: Plants, introduced herbivores and avian scavengers in the Canary Islands. Biodivers. Conserv. 2006, 15, 2231-2248. [CrossRef]

81. Palomar, C.J. El ratonero común (Buteo buteo insularum) en Fuerteventura, islas Canarias (Aves, Accipitridae). Vieraea 2005, 33, 1-10.

82. Post, P.; Götmark, F. Prey selection by sparrowhawks, Accipiter nisus: Relative predation risk for breeding passerine birds in relation to their size, ecology and behaviour. Philos. Trans. Biol. Sci. 1996, 351, 1559-1577.

83. Delgado, G.; Martin, A.; Quilis, V.; Emmerson, K. Diet of the sparrowhawk (Accipiter nisus) on the island of Tenerife. Doñana. Acta Vertebr. 1988, 15, 193-199.

84. Medina, F.M.; Martín, A. A new invasive species in the Canary Islands: A naturalized population of ferrets Mustela furo in La Palma Biosphere Reserve. Oryx 2009, 44, 41-44. [CrossRef]

85. Smith, G.P.; Ragg, J.R.; Moller, H.; Waldrup, K.A. Diet of ferrets (Mustela furo) from pastoral habitats in Otago and Southland, New Zealand. N. Z. J. Zool. 1995, 22, 363-369. [CrossRef]

86. Ragg, J.R. Intraspecific and seasonal differences in the diet of feral ferrets (Mustela furo) in a pastoral habitat, East Otago, New Zealand. N. Z. J. Ecol. 1998, 22, 113-119.

87. Bodey, T.W.; Bearhop, S.; McDonald, R.A. The diet of an invasive nonnative predator, the feral ferret Mustela furo, and implications for the conservation of ground-nesting birds. Eur. J. Wildl. Res. 2011, 57, $107-177$. [CrossRef]

88. Cole, F.R.; Loope, L.L.; Medeiros, A.C.; Howe, C.E.; Anderson, L.J. Food habits of introduced rodents in high-elevation shrubland of Haleakala National Park, Maui, Hawaii. Pac. Sci. 2000, 54, 313-329.

89. Towns, D.R.; Atkinson, I.A.E.; Dagherty, C.H. Have the harmful effects of introduced rats on islands been exaggerated? Biol. Invasions 2006, 8, 863-891. [CrossRef]

90. Shiels, A.B.; Flores, C.A.; Khamsing, A.; Krushelnycky, P.D.; Mosher, S.M.; Drake, D.R. Dietary niche differentiation among three species of invasive rodents (Rattus rattus, R. exulans, Mus musculus). Biol. Invasions 2013, 15, 1037-1048. [CrossRef]

91. Chapuis, J.L. Comparison of the diets of two sympatric lagomorphs, Lepus europaeus (Pallas) and Oryctolagus cuniculus (L.) in an agro-ecosystem of the Ile-de-France. Z. Für Säugetierkunde 1990, 55, 176-185.

92. Martins, H.; Milne, J.A.; Rego, F. Seasonal and spatial variation in the diet of the wild rabbit (Oryctolagus cuniculus L.) in Portugal. J. Zool. 2002, 258, 395-404. [CrossRef] 
93. France, C.M.; Giaccai, J.A.; Cano, N. The effects of PVAc treatment and organic solvent removal on $\delta^{13}$ C, $\delta^{15} \mathrm{~N}$, and $\delta^{18} \mathrm{O}$ values of collagen and hydroxyapatite in a modern bone. J. Archaeol. Sci. 2011, 38, 3387-3393. [CrossRef]

94. Ambrose, S.H. Preparation and characterization of bone and tooth collagen for isotopic analysis. J. Archaeol. Sci. 1990, 17, 431-451. [CrossRef]

95. Skrypzpek, G. Normalization procedures and reference material selection in stable HCNOS isotope analyses: An overview. Anal. Bioanal. Chem. 2013, 405, 2815-2823. [CrossRef] [PubMed]

96. Stuiver, M.; Reimer, P.J.; Reimer, R.W. CALIB 7.1. Available online: http://calib.org (accessed on 2 January 2019).

97. Reimer, P.; Bard, E.; Bayliss, A.; Beck, J.W.; Blackwell, P.G.; Bronk Ramsey, C.; Buck, C.E.; Cheng, H.; Edwards, R.L.; Friedrich, M.; et al. IntCal13 AND Marine13 radiocarbon age calibration curves 0-50,000 years cal BP. Radiocarbon 2013, 55, 1869-1887. [CrossRef]

98. Mosher, S.G.; Crowley, B.E.; Diefendorf, A.D.; Brone, R.; Yanes, Y. Characterizing spatial variability in foliar carbon and nitrogen isotopes on Tenerife, Canary Islands. Oecologia, in preparation.

99. Francey, R.J.; Allison, C.E.; Etheridge, D.M.; Trudinger, C.M.; Enting, I.G.; Leuenberger, M.; Langenfelds, R.L.; Michel, E.; Steele, L.P. A 1000-year high precision record of $\delta 13 \mathrm{C}$ in atmospheric $\mathrm{CO}_{2}$. Tellus B 1999, 51, 170-193. [CrossRef]

100. Leuenberger, M.; Siegenthaler, U.; Langway, C. Carbon isotope composition of atmospheric $\mathrm{CO}_{2}$ during the last ice age from an Antarctic core. Nature 1992, 357, 488-490. [CrossRef]

101. Elsig, J.; Schmitt, J.; Leuenberger, D.; Schneider, R.; Eyer, M.; Leuenberger, M.; Joos, F.; Fischer, H.; Stocker, T.F. Stable isotope constraints on Holocene carbon cycle changes from an Antarctic ice core. Nature 2009, 461, 507-510. [CrossRef] [PubMed]

102. Schmitt, J.; Schneider, R.; Elsig, J.; Leuenberger, D.; Lourantou, A.; Chappellaz, J.; Köhler, P.; Joos, F.; Stocker, T.F.; Leuenberger, M.; et al. Carbon isotope constraints on the deglacial $\mathrm{CO}_{2}$ rise from ice cores. Science 2012, 336, 711-714. [CrossRef]

103. Indermühle, A.; Stocker, T.F.; Joos, F.; Fischer, H.; Smith, H.J.; Wahlen, M.; Deck, B.; Mastroianni, D.; Tschumi, J.; Blunier, T.; et al. Holocene carbon-cycle dynamics based on $\mathrm{CO}_{2}$ trapped in ice at Taylor Dome, Antarctica. Nature 1999, 398, 121-126. [CrossRef]

104. Strauss, D.; Sadler, P.M. Classical confidence intervals and Bayesian probability estimates for ends of local taxon ranges. Math. Geol. 1989, 21, 411-427. [CrossRef]

105. McFarlane, D.A. A comparison of methods for the probabilistic determination of vertebrate extinction chronologies. In Extinction in Near Time; MacPhee, R.D.E., Ed.; Kluwer/Plenum: New York, NY, USA, 1999; pp. 95-103.

106. Marshall, C.R. Estimation of taxonomic ranges from the fossil record. In Analytical PaleoBiology; Gilinksy, N.L., Signor, P.W., Eds.; University of Tennessee: Knoxville, TN, USA, 1991; pp. 19-38.

107. Crowley, B.E. A refined chronology of prehistoric Madagascar and the demise of the megafauna. Quat. Sci. Rev. 2010, 29, 2591-2603. [CrossRef]

108. Michaux, J.; López-Martínez, N.; Hernández-Pacheco, J.J. A ${ }^{14}$ C dating of Canariomys bravoi (Mammalia Rodentia), the extinct giant rat from Tenerife (Canary Islands, Spain), and the recent history of endemic mammals in the archipelago. Vie Milieu 1996, 46, 261-266.

109. Bearhop, S.; Adams, C.E.; Waldron, S.; Fuller, R.A.; MacLeod, H. Determining trophic niche width: A novel approach using stable isotope analysis. J. Anim. Ecol. 2004, 73, 1007-1012. [CrossRef]

110. Moller, H.; Alterio, N. Home range and spatial organisation of stoats (Mustela erminea), ferrets (Mustela furo) and feral house cats (Felis catus) on coastal grasslands, Otago Peninsula, New Zealand: Implications for yellow-eyed penguin (Megadyptes antipodes) conservation. N. Z. J. Zool. 1999, 26, 165-174. [CrossRef]

111. Yanes, Y.; Romanek, C.S.; Delgado, A.; Brant, H.A.; Noakes, J.E.; Alonso, M.R.; Ibáñez, M. Oxygen and carbon stable isotopes of modern land snail shells as environmental indicators from a low-latitude oceanic island. Geochim. Cosmochim. Acta 2009, 73, 4077-4099. [CrossRef]

112. Codron, J.; Codron, D.; Lee-Thorp, J.A.; Sponheimer, M.; Bond, W.J.; de Ruiter, D.; Grant, R. Taxonomic, anatomical, and spatio-temporal variations in the stable carbon and nitrogen isotopic compositions of plants from an African savanna. J. Archaeol. Sci. 2005, 32, 1757-1772. [CrossRef] 
113. Cernusak, L.A.; Tcherkez, G.; Keitel, C.; Cornwell, W.K.; Santiago, L.S.; Knohl, A.; Barbour, M.M.; Williams, D.G.; ReichI, P.B.; Ellsworth, D.S.; et al. Why are non-photosynthetic tissues generally ${ }^{13} \mathrm{C}$ enriched compared with leaves in $C_{3}$ plants? Review and synthesis of current hypotheses Funct. Plant. Biol. 2009, 36, 199-213. [CrossRef]

114. Blumenthal, S.A.; Rothman, J.M.; Chiritz, K.L.; Cerling, T.E. Stable isotopic variation in tropical forest plants for applications in primatology. Am. J. Primatol. 2016, 78, 1041-1054. [CrossRef]

115. Marzol-Jaén, M.V.; Sànchez-Megía, J.; García-Santos, G. Effects of fog on climate conditions at a subtropical montane cloud forest site in northern Tenerife (Canary Islands, Spain). In Tropical Montane Cloud Forests: Science for Conservation and Management; Bruijnzeel, L.A., Scatena, F.N., Hamilton, L.S., Eds.; Cambridge University Press: Cambridge, UK, 2010; pp. 359-364.

116. Parker, W.G.; Yanes, Y.; Surge, D.; Mesa-Hernandez, E. High-resolution paleoclimate reconstruction over the last two millennia in the eastern subtropical Atlantic Ocean. Gsa Abstr. Programs 2018, 50, 86. [CrossRef]

117. Gieger, T.; Leuschner, C. Altitudinal change in needle water relations of Pinus canariensis and possible evidence of a drought-induced alpine timberline on Mt. Teide, Tenerife. Flora 2004, 199, 100-109. [CrossRef]

118. Anderson, R.L.; Byrne, R.; Dawson, T. Stable isotope evidence for a foggy climate on Santa Cruz Island, California at 16,600 cal. yr. B.P. Palaeogeogr. Palaeoclimatol. Palaeoecol. 2008, 262, 176-181. [CrossRef]

119. Johnstone, J.A.; Dawson, T.E. Climatic context and ecological implications of summer fog decline in the coast redwood region. Proc. Natl. Acad. Sci. USA 2010, 107, 4533-4538. [CrossRef]

120. del-Arco, M.C.; del-Arco, M.M.; Atiénzar, E.; Atoche, P.; Martín, M.; Rodríguez, C.; Rosario, C. Dataciones absolutas en la prehistoria de Tenerife. In Homenaje a Celso Martín Guzmán; Millares, A., Carbrera, M.L., Peña, P.A., Eds.; Universidad De Las Palmas De Gran Canaria: Las Palmas de Gran Canaria, Spain, 1997; pp. 65-77.

(C) 2019 by the authors. Licensee MDPI, Basel, Switzerland. This article is an open access article distributed under the terms and conditions of the Creative Commons Attribution (CC BY) license (http:/ / creativecommons.org/licenses/by/4.0/). 